\title{
I. Milliyetçi Cephe Hükümeti: Siyasal Şiddet ve Devlet
}

\author{
Ayfer GENÇ YILMAZ
}

\section{Öz}

Çalışma, Türkiye’de I. Milliyetçi Cephe Hükümeti (1975-77) çatısı altında yaşanan siyasal şiddet olgusunu incelemek niyetindedir. Bunun için devlet zorunun söylem, pratik ve mekanizmalarına odaklanılacaktır. 31 Mart 1975 tarihinde kurulan ve AP, MSP, CGP ve MHP’nin hükümet ortağ 1 olarak yer aldığı I. Milliyetçi Cephe Hükümeti, 1970’li yılların toplumsal şiddetinin siyasal şiddete dönüşümünde merkezi bir rol oynar. Bu aşamada, dönemin siyasal aktörlerinin söylem, mekanizmalar (Emniyet Teşkilatı) ve pratikler (sıkıyönetimler) aracılığıyla siyasal şiddetin gelişiminde oynadıkları rol çalışma kapsamında analiz edilmek istenmektedir. Böylece, siyasal şiddet çalışmalarının ihmal edilen konuları olarak devlet ve kurumları çalışmanın merkezine yerleştirilecektir.

Böylesi bir analiz, ilk önce, devletin baskı aygıt ve pratiklerine siyasal elitler tarafından sağlanmak istenen meşruiyet mekanizması olarak işleyen güçlü devlet söylemine odaklanacaktır. Ardından, sıkıyönetimlerin bir baskı pratiği olarak nasıl işletildiğine ve bunların siyasal şiddet üzerindeki etkisine bakılacaktır. Son olarak, MC Hükümeti döneminde yapısal bir dönüşüm yaşayarak şiddetin merkezine yerleşen polis örgütü ele alınacaktır

Anahtar kelimeler: Siyasal şiddet, devlet, Milliyetçi Cephe, güvenlik, polis, sıkıyönetim

\section{First Nationalist Front Government: State and Political Violence}

\begin{abstract}
This study analyzes the political violence in Turkey under the First Nationalist Front Government (1975-77). For that purpose, I focus on discourses, practices and mechanisms of state repression in my analysis. The establishment of the First Nationalist Front Government by Justice Party, National Salvation Party, Republican Reliance Party, and Nationalist Movement Party in 1975 played an important role in the transformation of social violence into political violence. The political actors of this
\end{abstract}

* Araştırma Görevlisi, İstanbul Ticaret Üniversitesi Ticari Bilimler Fakültesi Siyaset Bilimi ve Uluslararası İlişkiler Bölümü; Doktora Öğrencisi Yıldız Teknik Üniversitesi İktisadi ve İdari Bilimler Fakültesi Siyaset Bilimi ve Uluslararası İlişkiler Bölümü. E-posta: ayfergenc@gmail.com 
period contributed to this transformation by using a strong state discourse as well as other mechanisms including the police organization and practices such as martial law. In that regard, the state and its institutions, which have been mostly neglected in the studies of political violence, are placed at the center of this analysis.

The analysis, firstly, focuses on the strong state discourse, which is utilized by political actors in order to legitimize the mechanisms and practices of state repression. Second, it concentrates on the martial law practice, its execution and its influence on political violence. Finally, the police organization, which underwent a structural transformation under the First Nationalist Front Government is examined.

Keywords: Political violence, the state, Nationalist Front, the police, martial law.

\section{Giriş}

Türkiye'de 1960'lı yıllarda filizlenen siyasal ve toplumsal muhalefet (Ünsal ve Keleş, 1982:7) 1970’lerin ikinci yarısına gelindiğinde karşıt radikal hareketlerin arttığı ve fiziksel şiddetin düzensiz kullanımının yoğunlaştı̆̆ı yeni bir dönemece girer (Gourisse, 2012). ${ }^{1}$ Söz konusu dönemi kaos, anarşi veya terör gibi makro kavramlar vasıtasıyla adlandırmak dönemin siyasal şiddetinin zamansallığını ve mekansallığını maskeler. Bu haliyle, siyasal şiddetin ortaya çıkışı ve gelişimini, ait olduğu siyasal ve toplumsal arka planı yok sayarak anlama çabası sağlıklı ve bilimsel bir analiz olanağını azaltır (Della Porta, 2008)

Sayari (2010), 1976-80 yılları arasında Türkiye’de siyasal şiddeti çözümlediği önemli çalışmasında ülkede 1968'li yıllarda gelişmeye başlayan öğrenci aktivizminin 1970'li yıllardan başlayarak ve özellikle 1970’lerin ikinci yarısında hızlanarak bir çeşit siyasal şiddet vakasına nasıl dönüştüğünü sorgular. Bunu yaparken daha çok sol örgütler, onların sol-içi bölünmeleri üzerinde durur. Bununla birlikte kentleşme, göç gibi sosyolojik açıklamaları da anarak siyasal şiddetin nedenlerini ana hatlar temelinde sıralar. Orlow (1982), döneme dair, erken tarihli çalışmasında siyasal şiddet olaylarını büyük ölçüde Kemalist modernleşmenin miras bıraktığı siyasal kültür üzerinden ele alır. Ünsal ve Keleş (1982) de 1975-80 arası siyasal şiddeti detaylı bir analize tabi tuttukları incelemelerinde kentleşme vurgusu temelinde dönemin şiddetini anlamaya çalışırlar. Gourisse (2010), 1975-80 yılları arasına odaklandığı yayınlanmış doktora tezinde devleti araştırmasının merkezine yerleştirmek suretiyle dönemin siyasal şiddetini çözümlemeye çalışır. Bu bağlamda Türkiye’de döneme dair akademik çalışmaların iddia ettiği "devletin yokluğu" ya da "devletin dışarıdalığı" tezinin aksine devletin, bizzat, oyunun kalbinde yer aldığını hatırlatır (Gourisse, 2012:175). Devletin, siyasal şiddet analizinde yerleşmesi gereken merkezi konumu vurgulayan bir diğer isim olarak Jacoby (2010:3), Türkiyede terörle mücadele ekseninde siyasal şiddeti incelediği makalesinde siyasal şiddetin genellikle komünist kalkışma, devlet-dışı aktörler, kentleşme ve siyasal kültür gibi makro nedensellikler üzerinden incelendiğini belirterek literatüre dair eksikliği

1 1960'lı yılların başında filizlenen af karşıtı öğrenci hareketliliği 1968 yllı ile birlikte yoğunluk kazanır. AntiAmerikancı gösteriler, Fikir Kulüpleri, üniversite işgalleri ile gençlik büyük bir dinamizm kazanmaya başlar (Aydınoğlu, 2007:216). 
bir kez daha vurgular. Davenport da (2007) buna paralel bir görüş belirtir: Araştırmacıların genelde hükümetlere ya da devlete karşı muhalif grupların yaptığı "kötülüklerle" ilgilendiklerini; buna karşın bizzat devlet tarafında olan biten karşısında sessiz kaldıklarını belirtir. Uysal’ın (2001) çalışması devletin güvenliği ve toplumsal muhalefet eylemleri arasındaki ilişkiyi Kalemli Çete örneği üzerinden çalışır ve bu anlamda toplumsal hareket ve devlet temelli yaklaşımları bir araya getirerek ilişkisel bir çerçeve sunar, ikisini birlikte anlamaya çalışır.

Bu bağlamda, çalı̧̧ma, Davenport ve Jacoby’nin vurguladıkları eksikliği göz önünde bulundurmak ve Uysal ve Gourisse'in devleti siyasal şiddetin kalbine yerleştiren çalışmalarını takip etmek suretiyle dönemin siyasal şiddetinin devlet söylemi, pratikleri ve mekanizmaları üzerinden tarihsel bir analizini gerçekleştirmek niyetindedir.

Bu bağlamda elinizdeki çalışma makro açıklamaların dışına çıkarak dönemin siyasal şiddetini tarihsel bir bağlama oturtmak amacıyla kısıtlı bir süreyi ele almakta ve bu kısıtlı sürede siyasal şiddetin devlet söylemi, pratikleri ile aygıtları aracılığıyla nasıl inşa olunduğunu anlamak niyetindedir. Bu bağlamda 1970’lerin ikinci yarısının hâkim yöneteni Milliyetçi Cephe hükümetleri siyasal şiddet ve devlet ilişkisi açısından önemli bir araştırma alanı olarak ortaya çıkmaktadır. Siyasal şiddet, her şeyden önemlisi, siyasi, hukuku ve ekonomik bir inşadır da (Ergut, 2014). Bu inşayı çözümlemek hedefi onu tarihsel olarak incelemeyi de zorunlu kılar.

I. Milliyetçi Cephe Hükümeti, dönemin siyasal şiddetinin devlet destekli en önemli aktörü MHP'yi de içine alan koalisyon anlayışıyla 1970'lerin ikinci yarısının şiddetine deyim yerindeyse yarı-resmi bir nitelik kazandırması açısından da önem kazanır (Orlow, 1982:68). ${ }^{2}$ Özetle, yukarıda ifade edilen teorik çerçeveyi pratikte incelemek açısından 1970'li yılların en uzun süreli hükümetini kurmayı başarmış I. MC Hükümeti önemli bir alan açmaktadır. Bu çerçevede, 30 Mart 1975 yllında göreve gelen ve dört sağ partinin (AP, MHP, MSP ve CGP) birleşiminden oluşan I. Milliyetçi Cephe hükümetinin siyasi kadro ve partilerinin siyasal şiddeti nasıl yönettikleri sorusu önem kazanmaktadır. Cephe’nin siyasal ve toplumsal muhalefet olaylarına bakış açısı, algılayışı ve bunları engellemek adına devletin baskı mekanizmalarını işleterek ortaya koyduğu politikalar çalışmanın inceleme konusunu oluşturacaktır.

Bu çerçevede, MC Hükümeti’nin aktörleri Muhtırảnın ve onu takip eden hükümetlerin işlettiği belli başlı baskı mekanizmalarıyla yönetmeye devam etmişler; üstelik bunu devletin milis gücü gibi işleyen MHP ortakllğında yaparak toplumsal şiddetin siyasal şiddete dönüşümünde önemli bir rol üstlenmiştirler. Bu bağlamda Muhtıra’nın sona ermesinden ve sivil yönetime geçişten dört yıl kadar sonra MC Hükümeti sıkıyönetim ve DGM uygulamalarına devam etmiş, buna, genişleyen polis kadroları ve kadrolaşma hareketini de eklemiştir. Özetle, siyasal şiddeti, bu çalışmanın yapmak istediği haliyle, tarihsel bağlamına yerleştirmek ve şiddetin nasıl işlediğine bakmak, 1970'li yılların ikinci yarısının siyasal şiddetini anlamak ve analiz edebilmek açısından

2 Elbette, daha 1968-71 döneminde Ülkücülerin AP destekli faaliyetleri söz konusudur. 1975’in ikinci yarısında MC Hükümeti ile birlikte değişen en önemli şey ise Ülkücülerin devlet mekanizmasında edindikleri konum ve bu sayede sağlayabildikleri meşruiyet olmuştur. Ülkücüler, bu şekilde, devlet söyleminde devlete yardımcı kuvvetler olarak anılmaya başlanmıştır. 
büyük önem taşımaktadır. Bu bağlamda, siyasal şiddetin ivme kazandığı dönem olan 1970’li yılların ikinci yarısının hâkim yöneteni olarak I. Milliyetçi Cephe Hükümeti şiddeti tarihsel bağlamda ve devlet ile kurumları üzerinden çalışmak bakımından önemli bir araştırma alanı olarak ortaya çıkmaktadır.

Böylesi bir analiz, ilk önce, devletin baskı aygıt ve pratiklerine siyasal elitler tarafından sağlanmak istenen meşruiyet mekanizması olarak işleyen güçlü devlet söylemine odaklanacaktır. Ardından, sıkıyönetimlerin ülke içi "meseleler" nedeniyle uzatılmak suretiyle bir baskı pratiği olarak nasıl işletildiğine bakılacaktır. Son olarak, MC Hükümeti döneminde yapısal bir dönüşüm yaşayarak şiddetin merkezine yerleşen polis örgütü devletle toplumun karşılaştığı alan olarak ele alınacaktır.

\section{Güçlü Devlet Söylemi ve Siyasal Şiddet}

Ünsal ve Keleş (1982:9) Türkiye örneği üzerinden 1970’li yılların ikinci yarısının siyasal şiddet olgusunu analiz ettikleri eserlerinde "otorite bunalımı"na bir iç etken olarak ayrı bir önem verirler. Laqueur’a referansla yaptıkları analiz ve onun sözleriyle vurguladıkları üzere "ülkemizde şiddet olaylarının yaygınlık kazanması teröristlerin çok güçlü olmalarından değil, hükümetin zayıf bulunmasından kaynaklanmaktadır." Bu tespit özellikle 1970'li yılların giderek artan dozdaki siyasal şiddet olaylarını anlamak açısından iki nedenle çok önemlidir:

Birincisi zayıf iktidar ya da dört partili I. MC Hükümeti, siyasal ajandalarındaki birçok farklılığa rağmen kritik bir noktada birleşirler. Bu amaç iktidarda kalmaktır. Toplumsal muhalefetin hızla yükseldiği ve hükümet içi çelişkilerin arttı̆̆ ş̧artlar dâhilinde iktidarda kalabilmenin yolu ise yoğunlaşan sol muhalefetin bastırılmasından geçmektedir. I. MC, 12 Mart Muhtırası́nın ve beraberinde getirdiği Anayasa değişikliklerinin devletin baskı aygıtını güçlendirmek amacıyla sunduğu yeni çerçeveden yararlanarak ama aynı zamanda onun yarım bıraktığı işi de tamamlamak amacıyla devlet aygıtını daha fazla güçlendirmenin peşine düşer. Türk sağının amiral gemisi AP (Turan, 2013) ve lideri Demirel'in 12 Mart rejiminin mirası sıkıyönetim pratiklerinden ve "sıkıyönetimsiz sıkıyönetim" olarak tasvir edilen DGM yargılamalarından yararlanması ve bunları kuvvetle savunması ancak bu çerçevede anlaşılabilir. Diğer bir deyişle, 12 Mart döneminin ve taraftarlarının ünlü sloganı “Son Türk devletini kurtaralım”, bu defa, 1975 ertesinin farklı dudaklarda tekrarlanan yeni sloganı haline gelir. Milliyetçilerin, devleti elinden kurtaracağı kamp elbette iç düşman olarak temsil edilen sol ya da komünistlerdir.

Bu kapsamda, I. MC'nin bir cephe olarak ortaya çıkması ve bu eksende siyasal amacını ve pozisyonunu anti-komünizm ya da komünizmle mücadele temaları üzerinde temellendirmesi, dönemin siyasal sistemini büyük ölçüde kutuplaştırıcı bir amaca hizmet etmiştir. Sonrasında Demirel önderliğindeki MC’nin siyasal söylemi de bu kutuplaşmayı beslemeye devam etmiştir. Siyasal söylemin kutuplaşması, nihayetinde, siyasal sistemin geleneksel köşelerine çekilmesine

3 Burada terörist sözcüğünün kullanılması çalışmanın genel mantığına ve amacına ters düşmekle birlikte, yazarların orijinal metnine ve ifadelerine dokunulmamıştır. 
neden olmuştur. Buna göre, bir tarafta kamu düzeni koalisyonu yer alırken diğer tarafta sivil hakları savunan bir diğer koalisyon oluşmuştur. İşte bu kutuplaşma, bizzat, kamu düzeni ittifakına güç kazandıran bir işlev üstlenmiştir (Della Porta, 2006). MC, devlet ve kamu düzeninden yana tavrını ortaya koyarken Cephe dışında kalan sol kesimi devlet düşmanlığı ile suçlamıştır. Solun hükümette yer almadığı böylesi bir siyasal atmosferde Cephe çatısı altında sağ partiler, devletin koruyucusu rolünü üstlenebilmişlerdir. Bu sayede, sol muhalefet toplumsal ve iktisadi içeriğinden soyutlanarak büyük ölçüde devlet düşmanı siyasal muhalefet konumuna yerleştirilmiştir.

İkinci olarak, I. MC, yukarıda ifade edilenlerle de bağlantılı şekilde, devleti sürekli korunması gereken, devamlı tehdit edilen ve tehlikede olan bir "şey" olarak inşa ederken, bu yolda tüm savunma mekanizmalarını meşrulaştırma amacına yönelmiştir. Hiçbir devlet saf güce dayanmaz (Uysal, 2012) ve baskı aygıtları her durumda siyasal elitler tarafından bir meşruiyet zeminine yerleştirilme ihtiyacı duyar. Devletin güvenliğine yönelik saplantı duygusu bu haliyle métaidéologie securitaire (Dorronsoro, 2006) halini alır ve meşruiyet mekanizması olarak işler. Bu bağlamda 12 Mart Muhtırası ertesinde yeniden suretini gösteren devleti güçlendirme arayışı ile ülkücü militanlar aynı hedef doğrultusunda bir araya getirilir. 12 Mart’n sıkıyönetim mahkemelerinin önemli yargıçlarından Saadettin Somuncuoğlu bu gerçekliği "Ülkücü gençler devletin emniyet kuvvetlerinin yanında komünistlere karşı savaşıyorlar” görüşünü mahkeme kararına geçirerek bir kez daha ispatlar (Cumhuriyet Gazetesi, 4 Mayıs 1976). Devlete yardımcı kuvvetler olarak sunulan para-militer devlet şiddetinin en önemli yüzü Ülkücüler de şüphesiz bu meşrulaştırma ve iktidara ortak etme yoluyla meşrulaştırma mekanizmasından yararlanmışlardır. Somuncuoğlu, daha sonra, MHP Genel Sekreter Yardımcısı olarak üniversiteyi ele geçirmek isteyen Marksist militanlara karşı MHP'li gençlerin okuma hakkını korumak için kanunlar önünde devlet kuvvetlerinin yanında olduklarını ve Marksist gruplarla çatıştıklarını söyleyecektir (Cumhuriyet Gazetesi, 14 Ocak 1976).

Bozarslan (2009) bir "bölücü ve birleştirici olarak şiddet"i incelediği makalesinde sembolik şiddetin farklı bir tanımını sunar: Buna göre; sembolik şiddet "fiziki şiddeti mümkün kılan, meşrulaştıran ve zaman içerisinde yeniden üreten bir şiddet" biçimi olarak tanımlanmaktadır. Diğer bir deyişle belirli düşünce, söylem ya da pratikler uygulanan fiziki şiddeti meşru kılabilir. $\mathrm{Bu}$ bağlamda, Türk sağının 1970’li yıllar dâhilinde giderek kuvvetlenen güçlü devlet arayışı ve bunun görünen yüzü olarak devletin korunmasına yönelik işleyen milliyetçilik önemli bir sembolik şiddet söylemi olarak analiz edilebilir. Devlet zorunu meşru kılan Kemalist ideolojinin de bir devamı olarak nitelendirilebilecek güçlü devlet arayışı ve anlayışı ya da MC’nin başbakanı Demirel'in deyimiyle devlete "demokratik otorite" kazandırma çabası muhalefeti kriminalleştirmeye hizmet eden bir devlet savunusuna sarılmakla sonuçlanır. ${ }^{4}$ MC Hükümeti örneğinde, muhalefetin kriminalleştirilmesi süreci dost/düşman ayrımının netlik kazanmasıyla da belirgin kılınır. Bir tarafta devleti koruyan, kollayan ve onu güçlendirmeye çalışan bir blok yani milliyetçiler; diğer

4 Cumhuriyet döneminin güçlü devlet arayışı ve bu uğurda zoru meşru kılma gayreti büyük ölçüde radikal modernleşme projesinin gerçekleştirilmesi amacına hizmet etmektedir. Bu bağlamda, devletin otoriter bir zemin üzerinde inşası koşulların tarihselliği hesaba katıldığında seçeneksiz görünmektedir (Mert, 2007: 9). 
tarafta ise devleti devirmeye, yeni bir düzen kurmaya çalışan ayrı bir kamp olarak solcular ya da komünistler yer alır. Zaman ilerledikçe, Demirel ve MC, 1971 Muhtırası̉nın siyasal şiddeti hukuki olarak inşa eden pratik ve aygitları reddeden muhalefeti devlet karşıtı olmakla, devleti savunmamakla suçlayacak ve bu vesileyle Bozarslan’n (2009) bahsettiği sembolik şiddet üzerinden politikalarına meşruiyet kazandırmak isteyecektir. Toplum bünyesinde yaratılan devletin yanında ya da karşısında durma ikiliği, MC’nin iktidarda kaldığı sürece boyunca işlettiği pratik ve aygitların yardımıyla siyasal şiddetin beslenmesine hizmet edecektir.

\section{Siyasal Şiddet: Pratik (Sıkıyönetim) ve Kurum (Emniyet Teşkilatı)}

Davenport'un (2006:1) vurguladığı üzere çok uzun zaman boyunca şiddet konusunda araştırmacılar dikkatlerini ağılıklı olarak hükümet-karşıtı kişi, eylem, asi ya da teröristler üzerinde yoğunlaştırmıştır. Madalyonun diğer yüzü olarak devlet üzerine araştırmalar biraz daha geri planda kalmıştır. Hâlbuki polis, asker, gizli servisler gibi devlet zorunun aktörleri de pekâlâ analiz edilmeyi hak etmektedir. Gourisse (2014), benzer biçimde, şiddeti otonom bir süreç olarak analiz eden ve devleti deyim yerindeyse bir hakem gibi toplumsal çatışmaların üzerinde ve ona dışsal bir konuma yerleştiren çalışmaların detaylı bir eleştirisini sunar. Devlet, siyasal şiddet analizinin etkin bir öznesidir ve sürece içkindir. Bu bağlamda muhalif toplumsal hareket tarafından "baskı" olarak nitelendirilen; devlet kanadının ise hukuk ve düzen adına uyguladığını iddia ettiği protestonun gözetimi -policing protest- mevzusu (Della Porta ve Fillieule, 2004:217) ile önlem olarak işletilen olağanüstü yönetim mekanizmaları ayrı bir incelemeye konu olmaya fazlasıyla değerdir.

"Protesto eylemleri konusunda hoşgörüden çok baskıya ve yasaklara dayanan yaklaşım tarih boyunca Türk devletinin izlediği temel politika haline gelmiştir” (Uysal, 2012:405). Bu bağlamda, Türkiye örneği incelendiğinde, 1970’li yılların ve özellikle bu sürecin ikinci yarısının artan siyasal şiddetini sol örgütlenmeler ve ülkücü hareket arasındaki mücadele üzerinden anlamaya çalışmak önemli görünse de yetersizdir. Tek başına aşırı sol ve sağ örgütlenmeler dönemin şiddetinin sorumlusu değildir. Diğer taraftan hükümetlerin göreceli zayıflığından, istikrarsızlığından söz edilebilir olsa da devlet kurumları, mekanizmaları, zor kullanımı, aygıtları ile bir bütün olarak düşünülmeli ve siyasetin tam da merkezinde yer aldığı gözden kaçırılmamalıdır. Devletin bizzat kendisi radikal karşıtlıkların hedefinde bulunan kaynak ve makamların kontrolünün sahibidir (Gourisse, 2012:175). Tilly (2009:50), benzer şekilde, şiddet ve devlet arasındaki ilişkiyi incelerken devletler arasında güçlü ve zayıf ayrımı üzerinden bir kategorizasyona gitse de nihayetinde tüm devletlerin silahlar, askeri birlikler gibi yoğunlaştırılmış şiddet araçlarının üzerinde denetim kurmaya devam ettiklerini belirtir. Bu nokta, devleti, her durumda toplumdaki şiddet olaylarının farklı seviyelerde de olsa tarafı yapar.

Bu bağlamda, siyasal şiddetin 1971 müdahalesi ertesi yeniden yükselişe geçtiği 1975 yllı ve sonrasında, 1970'li yılların en uzun süreli hükümeti olarak MC’nin devletin mekanizmaları ekseninde siyasal şiddeti nasıl körüklediği analiz edilmesi gereken önemli bir nokta olarak 
ön plana çıkmaktadır. 1975 yılında siyasal şiddetin artışında sosyo-ekonomik faktörlerin ve uluslararası konjonktürün önemli bir etkisi olsa da nihayetinde dönem MC hükümeti dönemidir. $\mathrm{Bu}$ bakımdan aşırı sol ve sağ grupların kamusal kaynakları ele geçirme konusunda verdikleri mücadeleden bir hayli beslenen siyasal şiddet, kurumları elinde bulunduran hükümetin bu aktörler karşısında aldığı önlemler ve faydalandığı mekanizmalar sayesinde de yükselişe geçmiştir. Bu çerçevede, siyasal şiddet konusunda devlete dair kaynaklara örgütler tarafından yapılan taarruz karşısında o kaynak ve kurumların resmi ya da legal sahipleri olarak görülen MC hükümetinin de savunma ve bazen de taarruz bazında verdiği cevaplar önem taşımaktadır.

\section{Sıkıyönetimler}

Davenport (2006) “devlet zoru ya da baskısı nedir” sorusu üzerine yoğunlaştığı makalesinde şiddeti tarif etmek üzere Goldstein’in tanımına referansla birey veya örgütler karşısında kullanılan fiziksel cezalandırmanın varlığına ya da tehdidinin mevcudiyetine atıfta bulunur. Diğer bir ifadeyle, fiziksel cezalandırma ya da şiddetin kullanılması ya da kullanılmadan evvel önleyici olarak tehdit biçiminde var olması devlet zor ve baskısını meydana getirir. Devletin baskı ya da zor mekanizmasının işleyişi büyük ölçüde tehdit seviyesinde kalmakta (Goldstein, 1978) ve bu bağlamda devlet karşıtı eylemler karşısında bir önlem oluşturma hedefine yönelmektedir. Bu sayede toplumsal muhalefetin başı devlet tarafından erken zamanda ezilebilmektedir.

Ergut (2001:71) polisin ordudan ayrışması ile vatandaşlık haklarının gelişkinliği arasındaki doğrusallığa vurguda bulunur. Eğer bir rejimde, ordu, halen, toplumsal hareketlerin bastırılmasında kullanılıyorsa, bu, devletin iktidarını topluma yayamadığı bir sistemden bahsettiğimiz anlamına gelir. 1975 yılının MC Hükümeti de bu bağlamda 1971 Muhtırası ertesinde darbe rejimi çatısı altında işletilen sıkıyönetim ve sıkıyönetim mahkemelerini toplumsal muhalefetle baş etmenin yolu olarak elinde tutmak ve uygulamaya devam etmek istemiştir. 12 Mart rejimi süresinde AP başta olmak üzere birçok siyasi parti sıkıyönetimin her iki ayda bir uzatılmasına olumlu oy vererek ülkenin üç yıl süreyle sıkıyönetim altında yönetilmesine evet demiştir. Bu bağlamda grevler yasaklanmış, işçilerin toplu sözleşme hakları kısıtlanmış, gerçek ücretler düşürülmüş, Anayasa değiştirilmiş ve DGM’ler kurulmuştur. Özetle 12 Mart rejimi sona erse de sıkıönetim devam etmiştir.

Örgütlenme, ifade özgürlüklerinin kısıtlanması yerine örgütlenme ve ifade özgürlüklerinin kısıtlanması gibi pratikleri mümkün kılacak şekilde sıkıyönetimin “iç güvenlik” gerekçesiyle MC hükümeti döneminde beş ay süreyle uzatılmak suretiyle kullanılması üzerinde durulması gereken bir öneme haizdir. İfade ve örgütlenme özgürlüğünü askıya alan sıkıyönetim gibi uygulamalar, devlet zorunun tehdit boyutunu oluşturduğu ölçüde iktidarın elinde ciddi bir savunma ve baskı mekanizması halini almaktadır. Neocleous'un (2006:197) olağanüstü hal uygulaması ile ilgili olarak söylediklerini pekâlâ sıkıyönetim bağlamında da düşünmek mümkündür. Bu gibi uygulamalar, büyük ölçüde, savaş ile ilgisizken; iktisadi düzenlemeler ve sınıf ilişkileri ile birebir ilişkilidir. Bu çerçevede işçi hareketinin 1970 15-16 Haziran’ılla yükselişe geçtiği ve DİSK’in daha fazla sayıda işçiye ulaşabildiği bir dönemde Demirel yönetimindeki MC de sıkıyönetimi Kıbrıs 
ile olası bir savaş bahanesi ile elinde bulundurmak ve yeniden yoğunlaşmak üzere olan toplumsal hareketi engellemek amaciyla kullanmak istemiştir.

1961 Anayasası, büyük ölçüde, hak ve özgürlükler lehine bir rejim ortaya koymuş olsa da MGK gibi bir yapıyı vücuda getirmesiyle birlikte ordunun siyaset içindeki yerini de kurumsallaştırmayı ihmal etmemiştir. 1971 Muhtırası, kendi tarafından, Anayasasının 44 maddesinde değişiklik yaparak devletin güvenliğini hak ve özgürlükler aleyhine ön plana alan bir yeni rejim ortaya koymuştur. Bu bağlamda, birazdan ele alacağımız devletin baskı aygıtını güçlendirecek çerçeve de bizzat Muhtıra aracılığıyla 1970’li yılların henüz başında çizilmeye başlamıştır.

Sıkıyönetim bir olağanüstü yönetim uygulamasıdır. Bu bağlamda, yönetime daha hızlı hareket edebilme, temel hak ve özgürlükleri daha fazla sınırlayabilme yetkisi tanımaktadır. Sıkıyönetimi düzenleyen 13 Mayıs 1971 tarihli ve 1402 sayılı yasayı da bu çerçevede değerlendirmek önemli görünmektedir. Sıkıyönetim, 26 Nisan 1971 tarihinde ilan edildiğinde uygulanmakta olan Anayasa 1961 Anayasası idi ve yine sıkıyönetim ilanını düzenleyen yasa da 22.05.1940 tarihli ve 3832 sayılı Örfi İdare Kanunu idi. Örfi İdare Kanunu, sıkıyönetimin ilanıyla birlikte yürürlükten kaldırıldı ve yerine 1402 sayılı Sıkıyönetim Kanunu yürürlüğe kondu (Üskül, 2014:2). Böylece sıkıyönetim kanunu bizzat sıkıyönetim altında değiştirildi. 12 Mart Muhtırası ertesi girişilen 1971 yılı yasa değişikliği ile Anayasanın sıkıyönetime dair esasları belirleyen 124. maddesine sıkıyönetime başvurmayı kolaylaştıran daha esnek ve muğlak kavramsal eklentiler yapılarak bu olağanüstü rejim başı dara düşen hükümetlerin hemen başvurabilecekleri pratik bir çare niteliğine büründürülmüştür (Cumhuriyet Gazetesi, 17 Şubat 1976). Böylece, 12 Mart döneminde yapilan Anayasa değişikliği ile var olan sıkıyönetim koşullarına bir yenisi daha eklenmiştir: "Ülkenin ve milletin bölünmezliğini içten veya dıştan tehlikeye düşüren veya hak ve hürriyetleri ortadan kaldırmaya yönelen yaygın şiddet hareketleri hakkında kesin belirtilerin ortaya çıkması". $\mathrm{Bu}$ maddenin hedefinde duran kitle, şüphesiz, öğrenci hareketleri, sol örgütlenmeler, ivme kazanmaya başlayan işçi hareketi ve sendikal harekettir.

Sıkıyönetimin 1970'li yıllardaki ilk uygulaması MC Hükümetinin kurulmasından çok önce, ama yine bir Demirel hükümeti döneminde 15-16 Haziran 1970 olaylarının ulaştı̆̆ boyut üzerine gerçekleşmiştir. Bunu takip eden süreçte sırasıyla önce 12 Mart Muhtırası rejimi sırasında iki yıl süreyle ülkenin belirli illeri sıkıyönetim ile yönetilmiştir. Bu süreç Kıbrıs Harekâtı öncesinde CHP’nin sıkıyönetim teklifi ile devam etmiş, ardından savaş koşullarının ortadan kalkmış olmasına rağmen bu defa ağırlıklı olarak iç güvenlik tehdidiyle sıkıyönetim mekanizması işletilmek suretiyle uzatılmıştır. Kıbrıs Harekâtı sırasında ve güvenlik gerekçeli gizlilik talebiyle uygulamaya konulan sıkıyönetim uygulaması, sonrasında Sadi Irmak Hükümeti tarafından uzatılmış ve bu defa iç güvenlik tehdidi de sıkıyönetim gerekçesi olarak Meclis tartışmasında öne sürülmüştür. MC hükümeti göreve geldiği 30 Mart 1975 tarihinden itibaren sıkıyönetim uygulamasının gerekçesi olarak iç güvenlik tehdidine daha büyük rol vermiş ve Kıbrıs harekâtı koşullarının durağanlaşmasına ve dolayısıyla savaş tehlikesinin ortadan kalkmasına rağmen sıkıyönetimi birer aylık sürelerle Temmuz 1975 yılına kadar uzatmıştır. 
Özetle, Demirel önderliğindeki MC Hükümeti, ki 1970’li yılların en uzun süreli hükümetini oluşturmaktadır, iktidarda kaldığı 26 aylık sürenin 5 aya kadar olan bölümünü sıkıyönetim altında ülkeyi yönetmek suretiyle iktidar olabilmiştir. Cephe Hükümeti bu 5 aylık süreç boyunca sıkıyönetimi giderek bir iç politika malzemesi olarak işletmeye çalışmıştır. Bu bağlamda, grev kırıcı, öğrenci hareketlerini yasaklayıcı, toplumsal hareketleri bastırıcı bir mekanizma yerine toplumsal hareketleri bastırıcı bir pratik olarak işleyen sıkıyönetim, Muhtıra ertesi kurulan sivil hükümetin yönetimi altında yeniden yeşermeye başlayan toplumsal muhalefeti büyümeden ezmek amacına hizmet etmiştir.

1975 yılının Nisan, Mayıs, Haziran ve Temmuz ayına ait TBMM tutanakları incelendiğinde sıkıyönetimin, dönemin siyaset sahnesinde, başlıca tartışma alanlarından biri olduğu kolaylıkla fark edilmektedir. Daha önce Meclis tartışmaları sırasında Bakanlar Kurulu’nun sıkıyönetimin uzatılmasına dair teklifinin bir gelenek olarak Başbakan ya da Dış İşleri Bakanı tarafından tüzük halinde meclis onayına sunulmasına karşın MC Hükümeti döneminde giderek bu görevin İç İşleri Bakanlığı tarafından üstlenildiği görülmektedir. Nisan 1975 yılına ait tutanaklarda "Kıbrıs'la ilgili genel durumun gerginliğini sürdürmesi ve iç güvenlik nedeniyle halen Ankara, İstanbul ve İçel illerinde uygulanmakta olan Sıkıyönetimin bir ay süre ile uzatılması" yönündeki MK kararının TBMM’ye arzını İçişleri Bakanı Oğuzhan Asiltürk geçekleştirmektedir. Asiltürk 30 Nisan 1975 tarihli konuşmasında sıkıyönetimin gerekçesi ile ilgili olarak iç olaylara vurgu yapmak suretiyle şu şekilde konuşmaktadır:

\begin{abstract}
"Sıkıyönetimin uzatılmasına dair Yüce Meclisimizin son karar tarihi olan 5 Nisan 1975 gününden bu yana, ülkemizde cereyan eden ideolojik amaçl amme nizamın bozucu, milli birlik ve gücümüzü sarsmaya matuf faaliyetler ve olaylar ciddiyetinden hiçbir şey kaybetmemiş, onu aynen muhafaza etmiş durumdadır. Nitekim legal ve illegal faaliyetlerde bulunan birtakım örgüt ve kişilerce banka soygunu, yıkıcı faaliyetleri teşvik ederek huzur bozmay amaçlayan bildiri ve beyannameler, silahlı ve silahsı çatışmalar, öğretim güvenliğini sarsıcı mahiyette üniversite ve yüksekokullarımızda sürdürülen boykot ve işgaller, ayrıca çeşitli kaynaklardan elde edilen istihbarat, bu konuda çok daha hassas ve uyanık olmamizi gerektirmektedir." (TBMM Tutanak Dergisi, 1975).
\end{abstract}

Milliyetçi Cephe döneminde iktidar partileri ve muhalif CHP arasındaki tartışmaların büyük çoğunluğu sıkıyönetim mevzusu üzerinde olmuştur. CHP’nin sıkıyönetim konusundaki karşıt ve kesin tavrı Ecevit'in meclis söylemlerinde sık sık yinelenirken Demirel ve koalisyon liderleri sıkıyönetimi iç güvenlik ve devletin bekası temelinde bir gereklilik olarak görmüşlerdir. MC Hükümeti mecliste süregiden tartışmalarda sıkıyönetimin uzatılması kararını sürekli olarak MGK’nın tavsiye kararına dayandırma yoluna gitmiştir. MC Hükümeti döneminde toplanan MGK sonrası hazırlanan bildirilerde boykotlar ve gösteriler kınanırken; bunlara yönelik gerçekleştirilen komando saldırılarından bahsedilmemesi de MC Hükümeti dâhilinde MGK’da yer alan MHP sayesinde Ülkücü komandoların devletin koruyucu şemsiyesi ve himayesi altına girdiğini göstermesi açısından da ayrıca vurgulanmaya değerdir. Bu çerçevede MC siyasi sorumluluğu da büyük ölçüde üzerinden atmaya çalışmıştır. 12 Mart Muhtırası̀nın izlerini üzerinden atamayan Demirel, bu sayede, sıkıyönetim gibi önemli bir konuda orduyu sahnenin 
önüne iterken kendi hükümetini arka planda bırakmayı tercih etmiştir.

$\mathrm{Bu}$ noktada bir gerçeğin altının çizilmesi önemlidir: MC döneminde MGK'daki asker-sivil dengesi büyük ölçüde değişmiştir. Dönemin dört partili koalisyon hükümeti olarak Milliyetçi Cephe bünyesinde koalisyonu oluşturan partilerin genel başkanları başbakan yardımcısı olarak görev yapmışlardır: Alpaslan Türkeş, Turan Feyzioğlu ve Necmettin Erbakan; Demirel başbakanlığındaki hükümetin başbakan yardımcılarıdır. Üç adet başbakan yardımcısına sahip bir hükümetin MGK'daki ağırlığı da şüphesiz farklı olmuştur. Bu sivil üyeler arasında milis kuvvetlerin başı olarak Türkeş’in yer alması da komandoların deyim yerindeyse MGK bildirisi ile himaye görmelerini sağlamıştır denilebilir.

Sıkıyönetim mekanizmasının işletilmesi konusu ele alındığında önemle üzerinde durulması gereken bir husus bu yönetim biçimin kendine has bir uygulama mevzuatı olmadığıdır. Bu durum, sıkıyönetim ilan edilen ilin yönetiminden sorumlu komutanın belirleyeceği bir keyfi yönetimi biçimi ortaya koymaktadır. Ayrıca sıkıyönetim komutanları Başbakana tabi durumdadır. Bu da idareye siyasi sorumluluktan kaçmak suretiyle kanun-dışı çerçevede yine keyfi bir yönetim gerçekleştirme fırsatını sunmaktadır. Bu noktada sıkıyönetimin MC Hükümeti dönemi süresinde uygulanış tarzı önemli bir soru işareti oluşturmaktadır.

Sıkıyönetimin iç tehdit üzerine yoğunlaşması da sıkıyönetim uygulamasında asker-sivil dengesini değiştirmektedir. Dış tehlikenin var olduğu durumlarda asker, sıkıyönetim uygulamasında daha büyük ağırlık kazanırken; dış tehlikenin azaldığı ve iç tehdidin baş gösterdiği durumlarda ağıllık sıkıyönetimin bağlı olduğu sivil iktidar odağına yani başbakana kaymaktadır. Bu da askeri idarenin iktidardaki hükümetin tesiri altına girmesi anlamına gelmektedir.

Sıkıyönetimin MC Hükümeti döneminde nasıl işlediğine bakıldığında özellikle Ankara Sıkıyönetim Komutanlığı’nın yetki alanına giren bölgede çok sayıda gösteri, örgütlenme ve siyasal faaliyetin yasaklandığı gözlenmektedir. 1975 yılı süresince Ankara Sıkıyönetim Komutanı, ODTÜ olayları sırasında öğrencileri direnişten vazgeçirmeye çalışmış ve yine benzer şekilde Sıkıyönetim Komutanlığı CHP Genel Başkanı Ecevit' in Kırıkkale’de yapacağı konuşmaya da izin vermemiştir. Ecevit, Sıkıyönetim Komutanlığı tarafından mitinglerinin iptal edilmesi ve yine Ankara Sıkıyönetim Komutanı tarafından demeçlerine yanıt verilmesi sonrasında endişelerini paylaşma gereği duymuştur. Ecevit'in Kırıkkale toplantısı yasaklanırken aynı yerde Erbakan’n konuşmasına izin verilmesi de, yine, Sıkıyönetimin hükümet tarafından keyfi bir yönetim biçimi olarak kullanımına örnek oluşturmaktadır (Yankı Dergisi, 10-16 Ağustos 1975).

Sıkıyönetim Kanunu incelendiğinde söz konusu uygulamanın imkân verdiği üzere herhangi bir vatandaşın 15 gün sorgusuz sualsiz cezaevinde kalmasını mümkün kıldığı ve bu 15 günlük gözaltı süresi zarfında hiç kimseyle temas ettirilmemesini şart koştuğu fark edilmektedir. Yankı Dergisi’nin sıkıyönetim dönemlerinde gözaltına alınan kimselerle yaptı̆̆ı röportaj dosyası söz konusu yönetim mekanizmasının bireyler üzerinde bıraktığı psikolojik etkiyi de göstermesi açısından önemlidir. Buna maruz kalan kişiler, tutuklanmalarının nedeninin kendilerine bildirilmediğini, tek başına koğuş ya da hücrelere konulduklarını, bu tek kişilik kapatılmalar 
süresinde 15 gün dış dünya ile hiçbir etkileşimlerinin kalmadığını belirtmektedir (Yankı Dergisi, 10-16 Ağustos 1975)

Goodwin'in önemle belirttiği üzere silahlı ayaklanmalar büyük ölçüde devlet tarafından siyasal faaliyetlerin şiddetle bastırılması sonucu oluşur. Goodwin'in bu sözüne şu şekilde bir ekleme yapılırsa tam olarak 1975 yılındaki artan şiddet olaylarının açıklanabileceği bir zemin oluşturulabilir: Silahlı ayaklanmalar, siyasal faaliyetlerin şiddetle bastırılması sonucu hızlanır, şiddetlenir ve radikalleşir. Devlet mekanizmasının bir siyasal strateji olarak güvenlik politikalarını toplumsal muhalefeti bastırmada kullanması siyasal şiddeti arttırıcı bir rol oynar. Bu çerçeveden bakıldı̆̆ında sıkıyönetim uygulamasının kalkmasıyla birlikte toplumsal muhalefetin kazandığı yeni ivme önemli bir analiz noktası olarak ortaya çıkar. Sıkıyönetimin kaldırılmasıyla birlikte muhalefetin daha güçlü bir biçimde ivedilikle ortaya çıkması toplumda zaten var olan muhalif tavrın sıkıyönetime tepkiyle birlikte kümülatif biçimde birikimine neden olur. İbrahim Güzelce’nin bu konu hakkındaki fikirleri, bu bağlamda, not edilmeye değer görünmektedir:

“... bir yılı aşkın bir süre devam eden sıkıyönetimin geçenlerde kamuoyu ve ilerici, demokratik güçlerin baskısı sonucu kaldırılması üzerine işçi direnişlerinin yaygınlaştığı bir gerçek...

Ulusal güvenlik gerekçesiyle ilan edilmiş olmasına rağmen Anayasal hak ve özgürlüklere karşı kullanılan sıkıyönetimin kalkmasıyla yoğunlaşan demokratik işçi hareketleri bir yönüyle de bu baskı dönemine, anti demokratik uygulamalara yönelmiş bir tepkidir." (Yankı Dergisi, 24-30 Ağustos 1975).

Beş aya yakın bir süre sıkıyönetim mekanizmasını işleten dört partili MC Hükümeti uygulamanın kalkmasından sonra da başta Demirel ve Türkeş’in ısrarlarıyla sürekli olarak sıkıyönetim tehdidini canlı tutmuşlardır. Öyle ki The Guardian Gazetesi 1975 yılında sayfalarında yer alan bir yorumda MC Hükümeti ve Demirel'in sıkıyönetim getirmeye özellikle çabaladıklarından bahsetmektedir. Paralel biçimde, İsmail Cem (1980:7-50) AP liderliğindeki milliyetçi koalisyon hükümetinin toplumsal muhalefetin bastırılmasına yönelik demokrasi-dışı ve ordu temelli önlemler almaya başladığını, ortamı askeri bir yönetim için hazırladığından bahsetmektedir. Denilebilir ki sıkıyönetimin kalkmasından sonra dahi sıkıönetim söylemsel bir tehdit mekanizması olarak kamuoyu nezdinde sürekli anımsatılmak suretiyle güvenlikçi bir politikanın izlerini taşımaya devam etmiştir.

Demirel, öğrenci ölümlerini takip eden günlerde gerekirse üniversite yönetimine el konulabileceğini, o da yetmezse sıkıyönetim ilan edilebileceğinden bahsetmektedir. Sıkıyönetim rejimine ısrarla karşı çıkan Ecevit'in muhalefeti karşısında Demirel, CHP liderini "anarşi tahrikçiliği" ile suçlamaktadır. Demirel, "sıkıyönetim ihtiyaç haline gelirse ona itiraz ettiğiniz takdirde iki şeyden birini tercih ediyorsunuz demektir. Birisi anarşinin devamı, öbürü anarşinin önlenmesi” şeklinde konuşarak tartışmanın taraflarını keskin bir hatla ikiye bölmektedir (Cumhuriyet Gazetesi, 17 Ocak 1976). Benzer şekilde MHP Genel Sekreter Yardımcısı Sadi Somuncuoğlu da "ihtiyaç duyulduğu takdirde kanunların ve Anayasanın emrine göre hareket edileceği tabiidir” diyerek sıkıyönetimin anayasaya uygunluğunu vurgulamaktadır (Cumhuriyet 
Gazetesi, 14 Ocak 1976).

Sonuç olarak Türkiye siyasal tarihinde ağırlıklı olarak dış tehdit algısı ve savaş halinin gerekleri uyarınca kullanılan sıkıyönetim mekanizması, MC döneminde deyim yerindeyse olağanüstü bir yönetim biçimi olmaktan çıkıp sürekli bir hal almış ve birer aylık sürelerle uzatılmak suretiyle sıradan bir yönetim tarzı haline gelmiştir. İstisnai olan -ya da olması gereken- iç güvenlik tehdidi bahanesiyle kural haline getirilmiş ve böylece toplumsal muhalefet karşısında idareye güç kazandıran bir yeni yetki alanı açılmıştır. Toplumda hali hazırda var olan muhalefet, sıkıyönetim altında baskılandıkça birikmiştir. Sıkıyönetimin kalkması sonrası ortaya çıkan muhalefet bu haliyle daha şiddetli ve yoğun bir görünüme sahiptir.

\section{Emniyet Teşkilatı}

"1975 yıll, polis örgütünün yapısının köklü değişime uğramaya başladiğı bir dönüm noktası oldu. O dönemde hem kendi gözlemlerime hem de politikanın içinde olan ailemin gözlemlerine dayanarak, Milliyetçi Hareket Partisinin poliste nasıl örgütlendiğini takip ediyordum. Öner, 2003:34)

"Son dönemde ideolojik kadroların oluşturulması çabalarının kamu hizmetini aksattığı, kamu huzurunu bozduğu, iç barışı tehlikeli bir biçimde tehdit ettiği, Atatürk devrimlerine, layık demokratik ve hukuk devleti ilkelerine ters tutum ve davranışlar içine girildiği, Türk polisince üzüntüyle izlenmektedir." (Polis Derneği Genel Kurul Bildirisi'nden aktaran Öner, 2003:63)

"Suçlu oldukları kesin olan ve olay yerinde yakalanarak polise teslim edilen sanıkların salvverilmeleri hangi kanuna, yetkiye dayandirılmaktadır. Bu tip lakayt tavirlar bizi korkunç bir tespite götürmektedir. Üstelik bu tavirlar hep tek taraflı olmaktadır. Ülkücüleri hapse atmak için suç ve bahane arayan, fakat kızıl komünist militanların bir sürü görgü taniğının önünde işledikleri hunharca cinayete seyirci kalı örtbas etmeye gayret eden bu zihniyet kime ve neye hizmet etmektedir?” (Devlet, 29 Eylül 1975)

Yukarıda yer verilen alıntıların gösterdiği üzere, polis, 1970’li yılların ikinci yarısının ve özellikle Milliyetçi Cephe Hükümeti dönemi siyasal şiddet tartışmalarının odaklandığı ve aynı zamanda üzerinden kutuplaştığı örgütlenme olarak ortaya çıkmaktadır. Sonradan, döneme dair yapılan çalışmalar polis ve Emniyet Teşkilatı’nı büyük ölçüde yok saymış olsa da ${ }^{5}$ ikisi, hem döneme dair çalışmalar hem de siyasal şiddet analizi açısından merkezi bir öneme sahiptir. Çalışmanın bu bölümü, polisi çalışmanın konusunu oluşturan dönem dâhilinde ve devletle toplum ilişkiselliğinin gözlemlenebildiği bir alan olarak analiz etmek niyetindedir.

Polisin iç dinamiklerini ve yapısını dikkate almayan çalışmalar, onu, otoriteryanizm ve devlet şiddetinin abartılmış bir silahı olarak nitelendirme riskini taşır. Della Porta ve Fillieule (2004: 218), polisi hükümetten aldığ 1 emirleri uygulayan devlet aygıtının elinde basit bir silah olarak nitelendirmenin yerinde bir analiz biçimi olmayacağını belirtir. Diğer bir deyişle, polis, siyasal

5 Bu konudaki önemli bir istisna, Burak Gürel'in "Communist Police!" The State In The 1970s Turkey (2004) adlı çalışmasıdır. 
şiddet analizinde özel ve etkin bir aktör olarak yer almalıdır. Bu bakımdan, siyasal şiddet analizi polisi detaylı bir biçimde incelemeyi gerekli kılar.

Diğer taraftan devletin kurumlarını, zaman ve mekân bağlamında devlet-toplum diyalektiğinin aldığı farklı formlar temelinde düşünmek ve yine bu kurumları toplumsal ilişkilerin gerçekleştiği alanlar olarak algılamak (Aymes, Gourisse ve Massicard, 2014) Emniyet Teşkilatı üzerine yapılacak bir çalışma için önemli bir teorik başlangıç noktası oluşturmaktadır. Ergut'un (2001:62-63) polis çalışmaları için kavramsal bir çerçeve öneren makalesinde belirttiği üzere "polislik işi, esas olarak insanların gündelik hayatlarını kontrol altına alma yolunda devlet ve toplumsal güçlerin giriştikleri mücadelenin temel arenalarından biridir." Çalışma; bu çerçevede, dönemin Emniyet Teşkilatını devlet toplum ilişkisine ve diyalektiğine dayanmak suretiyle ele almak niyetindedir.

30 Mart 1975 yllında iktidara gelen MC Hükümeti bağlamında siyasal şiddet konusu devlet ve kurumları üzerinden incelenmek istendiği takdirde üzerinde durulması gereken en önemli kurumsal yapı olarak Emniyet Teşkilatı öne çıkar. Öyle ki, daha sonra 1970'lerin ikinci yarısında görev yapmış olan polis memurları tarafından kaleme alınan anılarda MC Hükümeti’nin göreve geliş tarihi olan 1975 yılı kurumun iç örgütlenmesi ve yapısı açısından bir nevi dönüm noktası olarak işaret edilir (Öner, 2003; Varlı, 1995). Dönemin önemli polis örgütlenmelerinden olan Pol-Der, Polis Enstitüsü Mezunları Derneği (POLENS) ve Uluslararası Polis Birliği (IPA) Türkiye Temsilciliği gibi derneklere ait Genel Kurul toplantıları, dergiler, gazeteler, bildiriler ve basın açıklamaları gibi çok sayıda belge de Emniyet Teşkilatı’nın MC Hükümeti döneminde geçirdiği yapısal değişimi -ya da dönüşümü- önemle vurgular. Adı geçen dernek ve örgütlenmeler, 1975 yılından itibaren hiç olmadığı kadar aktif bir politika izlemeye başlarlar ve kamuoyu nezdinde daha geniş bir görünürlük kazanırlar. Bunun nedeni, şüphesiz ki, birazdan detaylarıyla ele alınacağı üzere MC’yi oluşturan siyasal partilerin kurum içinde giriştikleri yoğun kadrolaşma çabaları, hükümetin Emniyet Teşkilatına doğrudan müdahalesi ve müdahale yoluyla kurum içine deyim yerindeyse "hükümet komiserleri" yerleştirme politikasıdır. Ülkücülerle organik bağ 1 bilinen MHP’nin 1975 yılıyla birlikte hükümet ortağı olduğu anımsandığında ve Ülkücülerin yetkili ağızlarda polise yardımcı kuvvetler olarak sunulmasının katkısıyla polis örgütlenmesinde yaşanan yapısal dönüşümün siyasal şiddet konusu ile olan bağı daha rahat anlaşlabilir.

Kadrolaşma, Türk siyasal kültürüne yerleştiği haliyle çoğu siyasal partinin iktidara geldiğinde uyguladığı bir politikadır. Özetle, Türkiye’de siyasal kültürün bir parçasıdır. Bununla birlikte durumu MC bağlamında farklı kılan etmenlerden en önemlisi hükümet ortaklarından MHP'nin devletin milisi gibi çalışan Ülkücülerle olan organik bağı ve diğer taraftan da MC’nin kadrolaşma çabalarının ülkenin toplumsal hareketlilik açısından yoğun günler yaşadığı bir döneme denk gelmesidir. Bu yoğun hareketlilik içinde silaha ve suçluların kovuşturulması gibi yargıyı da doğrudan ilgilendiren ve diğer devlet memurları ile kıyasla kamu güvenliği hususunda özel yetkilere sahip polise yönelik işletilen partizan politikalar ve siyasal bölünme, elbette ki, farklı sonuçlara gebedir. Öte yandan, MHP’nin Emniyet Teşkilatı içindeki kadrolaşması şüphesiz çok daha yoğun ve etkin bir biçimde gerçekleşecek ve hissedilecektir. MSP’nin -ki hükümetin İçişleri Bakanı MSP'li Oğuzhan Asiltürk'tür- bu yöndeki çabaları dahi Ülkücülerin kadrolaşmaları 
yanında büyük ölçüde etkisiz kalacaktır. Devletin gayr-1 resmi milis gücü olarak çalışan Ülkücülerin devletin kamu düzenini korumakla mükellef kurumunda edindiği resmi konum toplumda hüküm süren şiddetin rengini de değiştirecektir.

\section{- Să̆ Siyaset, Polis ve Şiddet}

Dünyada son dönemde sosyal bilimciler tarafından neoliberal sağ iktidarlara yönelik yapılan önemli tespitlerden biri de polis gücünden yararlanmaları ve ona dayanmalarıdır. Diğer bir deyişle vurgulanan neoliberal politikalar karşısında gelişen toplumsal muhalefetin polis yardımıyla ezilerek uygulandığı gerçeğidir. Bu tespit büyük ölçüde doğru olmakla birlikte, siyasal iktidar-polis ilişkisi Türkiye siyasal tarihinde yeni bir gelişme değildir. Tanıl Borảnın (2011) tespitiyle "Türkiyede milliyetçi-muhafazakâr ideoloji, öteden beri, tam da bir iç düşman tehdidi algılamasına dayanarak, polisi orduya 'eş koşmuş' ve onun azamî kuvvetlenmesini istemiştir." Emniyet teşkilatı, bu çerçevede, sağ siyasal iktidarların kilit hedeflerinden biri halini almıştır.

MC Hükümeti’nin iktidara geldiği tarihlerde Hükümete yakın sağ basında artan toplumsal hareketliliğe de paralel olarak polisin önemine yapılan vurgu artmıştır. Polisin güçlendirilmesi ile devletin güvenliğinin eş değerliliğine bu dönemde yapılan yoğun vurgu sağ siyaset, kuvvetli iktidar ve güvenlikçi devlet temalarıyla da örtüşmektedir. Tercüman Gazetesi'nin önemli yazarlarından Tarık Buğra (Tercüman, 22 Ekim 1975) aynı gazetedeki yazısında "Jandarma teşkilatını pek bilmiyorum; ama polis ve bekçinin yetersiz olduğunu duraklamadan söyleyebilirim. Bu yetersizlik sadece sayı bakımından da değildir; araç ve gereçler yönünden de öyledir” demektedir. Polisin güçlendirilmesinin gerekliliğine yönelik kamuoyunda oluşturulmak istenen ihtiyaç duygusuna güvenlikçi devlet anlayışına yapılan vurgu da eklenmektedir. Buğra, sözlerine şu şekilde devam etmektedir: "Devletin sıhhati -hiç değilse itibarı- sağladığı güvenliğe bağlı ve onunla orantılıdır. Bunun ilk ve bırakılamaz unsuru da polistir." Aynı yazar, yukarıda söylediklerine paralel bir biçimde, 12 Mart öncesinin devrimci yaygaralarından birisinin de polis devleti suçlaması olduğundan bahsetmektedir. Buna karşlık ise kendisinin buna "Elbette polis devleti" diye cevap verdiğini; zira polis devletinin tek alternatifinin süngü devleti olduğunu vurgulamaktadır (Tercüman, 16 Şubat 1976). Aydınlar Ocağı’nın önemli kalemlerinden Ergin’in (1975:149) vurguladığı üzere "Komünizmi önlemenin en vazgeçilmez şartı kuvvetli bir polistir. Polis, komünistlerin korkusu olmaktan hiçbir zaman çıkarılmamalı ve polisin kudreti her zaman komünistleri zararsız hale getirecek bir seviyede tutulmalıdır." Bu noktada denilebilir ki; Tercüman Gazetesi önderliğindeki sağ basın, toplumsal ve siyasal hareketlilik karşısında alınan ve alınacak olan güvenlikçi önlemler için zemin hazırlamaktadır.

\section{- MC Dönemi Polis, ve İktidar İlişkileri}

MC Dönemi polis politikalarının ayrıntısına girmeden evvel Türkiyede polisin durumuna çok genel olarak göz atmak önemli görünmektedir. Uysal (2006), polisin mesleki anlamda oynadığ 1 rolü nasıl algılandığını ve yine dış dünyayı anlamlandırma biçimini anlamanın "öncelikle kimlerin polis olduğu sorusunu yanıtlamaktan geçtiğini” belirtirken çok önemli bir noktaya temas eder. Gourisse (2008), Türkiyede polis kadrolaşmasını incelediği çalışmasında Türkiyede 
Emniyet Teşkilatı’nın, 1970’li yıllar boyunca kurumsallıktan uzak bir görünüme büründüğünü ve dışarıdaki siyasal bölünmüşlük ve kutuplaşmanın somut olarak gözlemlenebildiği bir mikro alan haline geldiğini tespit eder. Bahsedilen bu değişimin nedenlerini polislik mesleğine alımların öncesi ve sonrasında eğitime gereken önem verilmemesi, polis memurlarının çoğunun kültürel sermaye açısından fakir olmaları ve mesleğe alımda giriş sınavının yapılmaması gibi nedenlerle açıklamaya çalışır. ${ }^{6}$ Aynı nedenleri, polis teşkilatının maruz kaldığı ya da bırakıldığı kadrolaşma ve siyasallaşma süreçlerinin temeline de yerleștirir. Buna ilaveten, mesleğe alındıktan sonra da polis memurlarının kuvvetli bir eğitimden geçmemeleri ya da daha doğru bir ifadeyle bu memurların çok kısa sürelere sığdırılmış eğitim dönemlerinde çok şey öğrenmek zorunda bırakılmaları mesleki eğitimi amacından uzaklaştırmakta ve basit bir prosedür haline getirmektedir.

Polis pratiklerini düzenleyen yasal mevzuata ve/veya bu yasalarda iktidarlarca gerçekleștirilen değişikliklere yakından bakıldığında devletin polis aracilığıyla nasıl bir düzen tesis etmeye çalıştı̆̆ı ve yine vatandaşlarla nasıl bir ilişki kurmayı hedeflediği büyük ölçüde ortaya çıkmaktadır (Gönen vd, 2013). MC Hükümeti döneminde polisliğe dair yasal çerçevede yönetmelikler aracıllğııla yapılan düzenleme ve değiş̧iklikler de bu çerçevede düşünülmelidir. Buna göre; MC Hükümeti 31 Mart 1975 tarihinde göreve gelir gelmez yasal pratikleri uygulamaya koymak suretiyle ve özellikle yönetmeliklerde değişiklikler gerçekleştirerek kurum içinde bundan sonra meydana gelecek yapısal ve örgütsel dönüşümlerin ilk adımını atar. Bu çabalar ise, nihayetinde, polisin artan toplumsal muhalefeti baskılayıcı bir araç haline getirilmesi amacına yönelik olarak siyasal iktidar elinde araçsallaştırılması çabası ile hızlanacaktır. Bu çerçevede, 1975 yılının Haziran ayından itibaren hükümetin en küçük ortağı olarak MHP’nin ve çok daha az yoğunluklu olmak kaydıyla MSP’nin kurumdaki kadrolaşma çabalarının AP’nin de desteği ile çok geniş boyutlara ulaşmaya başladığı tespitini yaparak konuya başlamak önemli görünmektedir. Kadrolaşma hareketi, doğası gereği, hem "diğerleri”ni dışlar hem de kurum-içi yapıyı siyasal bir renge boyar. Kuruma sadece dışarıdan yapılan siyasal atamalar etkide bulunmaz; aynı zamanda kurum içinde var olan kadrolar da kadrolaşma politikasından etkilenir. Üstelik kurum bünyesinde gelişen partizanlık ve siyasallaşmaya toplumdaki bölünme ve çatı̧̧manın akisleri de eklenir. En önemlisi ise, polis, her an görevden alınma tehdidiyle korku içinde görev yaparken hem kendi meslektaşının baskısıyla hem de halkın tenkidiyle karşılaştığı ölçüde kamu düzenini sağlama görevinden uzaklaşır.

MC dönemi polis alımları yukarıdaki tespitlerin ışı̆̆ı altında teşkilat içerisindeki siyasallaşma, kadrolaşma, partizanlık ve bölünme süreçlerini anlamak açısından can alıcı bir örnek oluşturur. MC hükümetinin görev süresinin henüz başında çıkartılan 1 Haziran 1975 tarihli yönetmelik değişikliği sonrası 2500 kadar polis alımının "askerliğini yapmış olma" şartı aranmaksızın gerçekleştirilmesi öngörülmüş̧ür. Bu şekilde "Emniyet Teşkilatındaki bir memuriyete ilk defa atanacaklar için zorunlu yeterlik ve yarışma sınavları" hakkındaki yönetmelikte önemli bir değişikliğe gidilmiştir. Böylece özel bir kanun olan Emniyet Teşkilatı Kanunu hiçe sayılarak 657

61975 yılında yayın hayatına başlayan ve birazdan daha detaylı bir biçimde analiz edilecek olan Polis Derneği’ne (PolDer) ait Pol-Der Gazetesi’nde polisin 1970'li yıllardaki eğitim durumu ve bu yönde süregelen yetersiz çalışmalar önemli bir eksiklik olarak üyelerin ve kamuoyunun dikkatine sunulmaktadır. 1975 yllında kurum içindeki ilkokul mezunu polis sayısı 30 bin olarak ifade edilmektedir (Pol-Der, Aralık 1975). 
sayılı Devlet Memurları Kanunu, polis alımlarında da uygulanmak istenmiştir. ${ }^{7}$ Bununla birlikte söz konusu 2500 kişilik kadroya polis alımı dilekçe ile başvuruyu esas almaktadır. Söz konusu kanun tasarısı özellikle MHP/Ülkücü kadroların ve İçişleri Bakanı Asiltürk’ün ısrarının gösterdiği üzere İmam Hatip kadrolarının polis teşkilatına yerleştirilmeleri tartışmalarını da beraberinde getirmiştir. Tartışma sol ve laik basında daha çok İmam Hatip mezunu olup olmama tartışması üzerinden ilerlemiş olsa da polis derneklerinin üzerinde durduğu asıl konu Emniyet Teşkilatı’na meslek dışından eğitim görmemiş kimselerin alınacak olması hususunda odaklanmıştır.

Danıştay’a bu yönetmeliğin iptali için başvuran Emniyet Amirleri, Pol-Der Başkanı Kazım Ulusoy, IPA Türkiye Temsilciliği Genel Başkanı Muzaffer Özbayrak ve Saffet Yüksel'dir. ${ }^{8}$ Buna göre; adı geçen dernekler, siyasal düşüncelerle yapılan atamaların ve yer değiştirmelerin polisi siyasal çekişmenin içine ittiği ve tarafsızlık anlayışını ortadan kaldırdığını kamuoyuna duyurmaktadır. Burada Emniyet Amirlerinin itiraz ettiği nokta meslek dışından örgüt içine atama yapılması çabasıdır. IPA Genel Başkanı Muzaffer Özbayrak’ın belirttiği gibi polis teşkilatı içerisinde polisi polis idare etmemektedir.

Konuyla ilgili olarak dönemin İzmir Emniyet Müdürü Gürbüz Atabek askerliğini yapmamış kişilerin polis yapılmak istenmesinin Emniyet Teşkilatları Kanunu'na aykırı olduğunu belirtmektedir. Paralel biçimde, polis olacaklar için en az 15 gün öncesinden ilan asılmasının gerektiği ve başvuran çoksa da imtihana gidilmesinin mecburiyeti yine Atabek tarafindan hatırlatılmaktadır.

MC Hükümeti çatısı altında polisin yaşadığı dönüşüm ve bunun beraberinde getirdiği gelişmeleri kabaca iki ana başlık altında toplamak mümkündür. Bu bağlamda, polis şiddetini 1970’ler Türkiyesi açısından farklı bir şekilde incelemeyi zaruri kılan önemli bir etken Emniyet Teşkilatı içinde polisin polise uyguladığı baskı ve şiddettir. Bu durum ise büyük ölçüde siyasi iktidarın örgüt dâhilinde giriştiği kadrolaşma ve siyasallaşma politikalarının sonucudur. Dolayısıyla MC Hükümeti dönemi Emniyet Teşkilatını incelemek yerine MC Hükümeti dönemi emniyet teşkilatının incelenmesi polisin toplumsal hareketler, öğrenci ve işçiler karşısındaki eylemlerinin analiziyle sınırlı kalamaz. MC Hükümeti, bu bağlamda, polis teşkilatının bizzat içerisinde gelişen siyasal şiddetin somut olarak gözlemlenebildiği tarihsel bağlama işaret eder. Kurum içinde kendini baskı, yıldırma ve bazen doğrudan fiziksel şiddet kullanımına kadar götüren polisin polise uyguladığı şiddetin bizzat Emniyet Teşkilatı açısından farklı sonuçları söz konusu olmuştur. Üstelik sonuçlar sadece Emniyet Teşkilatı sınırları içinde kalmamış; halk ve polis arasındaki ilişkide de yansımalarını bulmuştur.

7 Polis mesleğine girecek şahısların taşıması gerekli şartları belirleyen Emniyet Teşkilatı Hakkındaki 3201 sayılı kanunun 23. maddesidir. Bu kanun ve madde uyarınca askerliğini yapmış olma şartı polis olmak üzere başvuruda bulunacak kişilerde kesin bir biçimde aranmaktadır.

8 Danıştay 5. Dairesi ilgili yönetmelik değişikliğini Ekim 1975 tarihinde durdurmuştur. Danıştay kararında "Askerlik görevini yapmış olmak polislik mesleğinin asli niteliklerinden biridir." denilmektedir. Ancak uygulamada askerliğini yapmamış kimseler için belirli sayıda bir kadro ayrıldığını İç İşleri Bakanı Asiltürk kamuoyuna duyurmakta bir sakınca görmemiştir. 
Polis, devletin topluma en yakın unsurlarından biri olarak belirir. Polis, devletle özdeş gösterilmeye çalışılsa da içinde bulunduğu toplumsal çerçeveden de en fazla etkilenen devlet kurumudur (Ergut, 2001:63). Bu önemli analizin 1975 yılının Türkiye’sinde somutlandı̆̆ bir örgütün vücuda gelişi bu açıdan önemlidir. 1975 yılını polisler ve emniyet teşkilatı açısından deyim yerindeyse bir dönüm noktası olarak nitelendirmenin temelinde yatan diğer bir gelişme şüphesiz Pol-Der’in kuruluşudur ve yukarıda ele alınan gerekçelerle birebir bağlantılıdır. Pol-Der örgüte iktidar tarafından yapılan baskının hem nedeni hem de sonucu olması açısından önem taşır. Dernek, her şeyden çok Emniyet Teşkilatı’nın 1975 yılında içinde bulunduğu ve halkla ilişkisini de büyük ölçüde yıpratan konum ve şartlarını değiştirebilmek için kurulmuştur. ${ }^{9}$ Derneğin kuruluşunun temelinde yatan ana etken Pol-Der üyesi polislerin "halkın polisi" olma istekleri ve polis ile halk arasında kopan bağı yeniden kurma niyetleridir. Dernek, bunun yolunu hiçbir siyasal yapı ile özdeşleşmeden polis örgütünü tümden kapsamakta görmektedir. Buna paralel olarak Pol-Der 2. Genel Kurul'dan sonra “Tüm Ulusumuza” hitabıyla başlayan bir bildiri yayımlamaktadır ki bu bildiri polis ve toplum ilişkisinin geldiği noktayı göstermesi açısından da son derece önemlidir:

"Polis halkla organik bir birlik oluşturur; hizmet etmekte olduğu toplumundan ayrı değil fakat onun bir parçasıdır (...) yoksa polis, Anayasal ve demokratik hakların kullanılmasının önünde bir engel, öğrencilere küskün, toplantı ve gösterilere gereksiz müdahale eden, yurttaşlara kötü davranan bir örgüt değildir. Bu duruma çevrilmesine hiçbir zaman, hiçbir çevrenin gücü yetmeyecektir."

Emniyet Teşkilatı içinde halkın polisi olma iddiasındaki Pol-Der'in ortaya çıkışı polisin devletin baskı aygıtının homojen bir parçası olmadığını kanıtlaması açısından çok önemlidir. Ayrıca, kurumun, içinde toplumsal ilişkilerin geliştiği ve evrildiği bir saha olarak düşünülmesinin gerekliliğini ispatlaması açısından da ayrıca dikkat çekmektedir.

\section{- Pol-Der ve Pol-Der’e Yönelik Baskılar}

Kadrolaşma politikası ve buna karşı tepkilere ilaveten Pol-Der kurulduğu tarihten itibaren iktidarın desteği ve devlet mekanizmalarının kullanılması suretiyle çok sayıda provokasyona hedef oldu. Dolayısıyla MC’nin polis örgütü içindeki faaliyeti sadece kadrolaşmayla sınırlı değildi. Emniyet Teşkilatının içinden doğabilecek sendikal görünümlü, sol eğilimli tüm yapılanmalar karşısında da etkin bir baskı ve yıldırma politikası yürütüldü. Denilebilir ki; sadece Pol-Der üyesi olmak dahi birçok emniyet görevlisi için bir nevi sabıka kaydı halini aldı. Emniyet Teşkilatı içinde sosyal demokrat bir yapılanmayı engellemek suretiyle Pol-Der ilk günden "sol” ya da "komünist" olmakla suçlandı ve bölücülük yaptığ 1 öne sürüldü. Haziran 1976 tarihinde gerçekleşen 2. Genel Kurul sırasında Emniyet Müdürlügü̈’nden görevli kimseler toplantıya gelerek ihbar aldıklarını

9 Pol-Der kurulmadan önce emniyet örgütüne amir yetiştiren ve muayyen senelerde açllan orta(k) kursunu bitirenlerin üye olabildiği daha dar kapsamlı bir dernek mevcut idi. 1970’te, mevcut dernek, üye kapsamını biraz daha genişleten tüzük değişikliği ile Polis Derneği adını aldı. Bu derneğin başkanı Kemal Bilgen’di. Kemal Bilgen’in Mayıs 1975’te görevi bırakacağını bir fırsat olarak gören sol ve sosyal-demokrat eğilimli kişiler 17 Mayıs 1975 tarihli Genel Kurul'da yönetimi ele geçirdiler. Böylece bugün bildiğimiz ve tarihte polis örgütlenmesi açısından çok farklı ve önemli bir örnek oluşturan Pol-Der kurulmuş oldu. Derneğe her kademeden emniyet mensubunun üye olabilmesi de PolDer'in kuruluşuyla sağlanmış oldu (Pol-Der, 1975; Öner, 2003). 
ve Genel Kurul'da kavga çıktığını öğrendiklerini belirterek müdahalede bulunmak istemiştirler. Aynı Genel Kurul'da MHP ve Bozkurt rozetli toplu bir grubun salona girdiği ve sloganlar atmaya başladıkları belirtilmiştir. Bu grup içerisinde polis dışında öğrenci ve militanların olması ayrıca dikkat çekicidir. Bu grup içerisinden bir kişinin kendini Genel Sekreter olarak ilan etmesini takip eden süreçte ise Faruk Sükan’a söz verilmiştir. Faruk Sükan, konuşmasında, Emniyet Teşkilatı içinde sonradan teşkil edecek siyasal bölünmenin tohumlarını ekecek şekilde "Bu derneği solculara teslim etmeyin" uyarısını yapacaktır (Öner, 2003). ${ }^{10}$ Polis Enstitüleri Mezunları Derneği Genel Başkanı Mustafa Öncül, daha sonra, o günle ilgili şu sözleri söyleyecektir:

"Özellikle son bir senedir, alınan personelin oluşturduğu bir grup polisimizin 12 Haziran 1976 günü yapılan Pol-Der Genel Kurul toplantısina gelmeleri ve belli bir siyasal partinin sloganlarım kullanmaları diğer mensuplarımızı kızıllıkla suçlamaları, örgütümüzce siyasal görüş̧ bölünmelerinin eylemsel aşamaya dönüşme noktasında olduğunu açıkça göstermesine rağmen Emniyet Genel Müdürlüğ̈̈ ve İçişleri Bakanlı̆̆ı'nın hiç çaba göstermemesi..."(Cumhuriyet Gazetesi, 7 Temmuz 1976)

Provokasyonlar sağ basın aracilığıyla da devam etmiştir. Türk sağının önemli gazetelerinden Tercüman Gazetesi’nde bu dönemde Suna San tarafından sürdürülen Anahtar Deliği adlı köş̧ede de Pol-Dere yönelik suçlamalar yer almaktadır. Öner (2003:51), döneme dair anılarında, Suna San’ın köşesindeki ağır suçlamalar karşısında bir tekzip yayınlamak zorunda kaldıklarını ve buna ilaveten Suna San’ı da Derneklerinde ağırlamak istediklerini ancak sonrasında böyle bir kimsenin gerçekte var olmadığını öğrendiklerini iddia etmektedir.

"Suna San diye birinin olmadığın, bu sütunda yazan kişinin kadın değil erkek olduğunu ve devlet memurluğu yaptığın saptadıktan kısa bir süre sonra Tercüman Gazetesi o sütunu iptal etti. Pol-Dere yönelik saldirlar izleyen dönemde Hergün vb. MHP yanlsı yayın organlarında yoğunlaştı ve gitgide sertleşti."

1976 yılı Emniyet Teşkilatının içinde süregiden tartışmaların nasıl bir yoğunluk kazandığını birçok açıdan ispatlamaktadır. Polis teşkilatı içinde olan biten karşısında harekete geçen tek dernek Pol-Der değildir. POLENS ve İPA da bu dönemde birçok açıdan Pol-Der’i destekleyen bildirilere imza atmıştır. 20 Kasım 1975 günü Pol-Der ve İPA’nın kamuoyuna sundukları ortak bildiriden sonra 20 Nisan 1976 yılında üç derneğin ortak olarak yayınladıkları müşterek bildiriler iktidarı rahatsız ettiği ölçüde dernek üyesi polisler üzerindeki baskıyı artmıştır. Bildirilerde ağırlıklı olarak eşitlik, kıdem ve liyakat ilkelerine özen gösterilmesi istenirken, meslek dışından kuruma yapılan atamalara dikkat çekilmek istenmiştir (Pol-Der, Kasım 1975).

Söz konusu siyasal kadrolaşma iddiaları ve eğitimsiz kişilerin polislik mesleğine alınmaları

101960 yılının sonlarına doğru AP içinde Emniyet Teşkilatı tartışmalarına dair iki ana görüş belirmiştir: İçişleri Bakanı Faruk Sükan, polis teşkilatını adam akıllı genişletme ve kuvvetlendirme taraftarıdır. Bu şekilde güçlenen teşkilatın içine ise kendi siyasal görüşüne bağlı gençlerin yerleştirilmesi ve bu şekilde ordu içinde olası bir kıpırdanmada bu kuvveti güvenle kullanmak istemektedir. İkinci görüş ise Savunma Bakanı Ahmet Topaloğlu’na aittir. Topaloğlu, Sükan'ın projesine tamamen karşı çıkmaktadır. Sonuçta Demirel, Topaloğlu’ndan yana tavır almak suretiyle bu tartışmayı sona erdirmiş olsa da önce zımnen sonrasında ise alenen Emniyet Teşkilatı içindeki MHP kadrolaşmasını desteklemiştir (Yankı Dergisi, 16-22 Haziran 1975). 
Emniyet Teşkilatı içinde de çeşitli tartışmalar ortaya çıkarmıştır. Siyasallaşma ve bölünmüşlügün ötesinde meslek ahlakı ve liyakat ilkeleri çerçevesinde de polis örgütü içinde bir hayli işlerlik kazanmış olan partizanlık örgüte mensup kişileri rahatsız etmiştir. Tartışmalardan etkilenen polis akademisi mezunu nitelikli bir Emniyet Müdürü istifa etmekten başka çare bulamadığını belirtmektedir. İlgili Emniyet Müdürü’nün aşağıda aynen yer verilen satırları polisteki kadrolaşma ve siyasallaşmanın durumunu göstermesi bağlamında önem taşımaktadır:

"Ancak bu teşkilattan istikbal bekleyerek umut içinde geçirdiğim yıllar boyunca ve özellikle
son zamanlarda; beni ve benim durumumda bulunan arkadaşlarımı yok sayarak, meslek
dışından getirilen, mesleki bilgi ve gelenekten yoksun oldukları herkesçe malum bazı
şahısların benden kıdemsiz ve daha az tahsilli olmalarına rağmen yıldırım hızıla terfi
ettirildiklerini müşahede ettim." (Pol-Der, Mayıs 1976)

Bundan sonra giderek keskinleşen hatlar, polisin sol örgütü olarak Pol-Der'in MC'yi hedef alan açıklamalarında anlaşılmaktadır. Pol-Der, hükümetin tüm emirlerine uymak zorunda olmadıklarını; sadece yasalarla sınırlı olduklarını ve yasaya uymayan hiçbir eylemde bulunmamaları gerektiğini ısrarla vurgulamaktadır. Şüphesiz ki buradan çıkan anlam, polisin sol örgütlenmeler, işçi ve öğrenci hareketleri üzerinde baskı amaçlı kullanmak isteyen hükümet politikalarına karşı duruşudur.

Pol-Der'in giderek etkin bir demokratik kitle örgütü halini almaya başlamasıyla hükümetin dernek üzerindeki yıldırıcı ve baskıcı politikaları da daha fazla hissedilmeye başlanmıştır. Bu dönem boyunca Kazım Ulusoy gibi dernek üst yönetiminde yer alan kişiler ile sınırlı kalmamak kaydıyla çok sayıda polis, Pol-Der'e üye oldukları gerekçesiyle sürgünlere, aleyhlerinde açılan soruşturmalara, ödeneklerin verilmemesi gibi maddi mağduriyet ve hak kayıplarına, amirleri ve meslektaşları tarafından fiziksel şiddete, işkenceye varan uygulamalara maruz kalmışlardır. Varlı (1995:42) anılarında Pol-Der üyesi olan babasının evinin polisler tarafından nasıl basıldığını uzun uzun anlatmaktadır: ${ }^{11}$

\begin{abstract}
"Babamların evine "yasak yayın bulundurulduğu, mermi ve silah kaçakçılığı yaptığ yolunca bir ihbar üzerine baskın yapılmıştı. Sonradan öğrendiğimiz bu gerekçe asıl neden değildi. Asıl neden siyasiydi. Bu Pol-Bir'li polislerin kendileri gibi düşünmeyenler üzerinde baskı kurma ve yıldırma uygulamalarından başka bir şey değildi.”
\end{abstract}

Ayrıca, MC Hükümeti döneminde 5 Haziran 1974 tarihinde yürürlükten kalkan Polis Divanları tekrar işletilmek suretiyle polisin polisi yargılamasının önü açılmak istenmiştir. Amaç, polisin polis tarafından kontrol altında tutulmasını sağlamaktır. 1 Ocak 1975 yılından 2 Aralık 1975 tarihine kadar geçen sürede Emniyet Teşkilatı içerisinde 275 ihtar, 258 tevbih, 1365 maaş kat'ı, kıdem tenzili, 148 terfiin bir devre geciktirilmesi, 50 meslekten ihraç, 30 memuriyetten ihraç cezası olmak üzere toplam 2450 emniyet personeline ceza verildiği belirtilmektedir (Pol-Der, Ekim 1976). Yine aynı gazetede, bir önceki sayıda, yerleri değiştirilen emniyet müdürlerinin tam listesi yer almaktadır. 1976 yılında 52 adet İl Emniyet Müdürünün yerlerinin değiştirildiği ve yine

11 Bkz. (Yiyenoğlu, 1995:42). 
Emniyet müdür yardımcılarının da farklı illere nakledildiği bildirilmektedir. Bu yer değiştirme ve atamalar, 13 Ağustos 1976 tarihinde Resmi Gazetede yayınlanarak yürürlüğe girmiştir. Pol-Der’in bu tip baskılar karşısında, Pol-Der üyelerine yönelik olsun ya da olmasın- başvurduğu adres ise Danıştay olacaktır. 1976 yılının son ayında Danıştay 5. Dairesi Polis Derneği yöneticilerinin taşra illerine nakline ilişkin idari işlem hakkında yürütmeyi durdurma kararı almış, konu ile ilgili olarak da idarenin savunmasını istemiştir (Milliyet Gazetesi, 25 Aralık 976). Bu dönem boyunca Danıştay birçok polis memuru hakkında verilen sürgün, atama, ihraç kararlarını memurlar lehine bozmuştur. Ancak uygulamada Danıştay kararı iktidardaki hükümet tarafından büyük ölçüde es geçilmiştir.

19 Ekim 1976 tarihinde Pol-Der "Sıkılır Ama Bu Kadar Da Sıkılmaz" başlıklı basın bülteninde İçişleri Bakanlığı̀na kapsamlı bir eleştiri yöneltmektedir. 1977 yılına gelindiğinde ise Pol-Der’in Adana, Antep, Adıyaman, Erzurum, Samsun, Trabzon yöneticileri ile Nevşehir, Kocaeli, Kayseri temsilcilerinin birtakım düzmece suçlamalarla soruşturuldukları ve sürgüne yollandıkları gerekçesiyle çok sayıda basın bildirisi Dernek tarafından hazırlanmaktadır (Öner, 2003).

Üstelik hükümetin baskı politikaları sadece Pol-Dere aktif üye olan kişilere uygulanmakla sınırlanmamıştır. Polis Enstitüsü’nde öğrenim gören bir öğrenci derste öğretim üyesi ile girdiği tartışma gerekçe gösterilerek idare tarafından öğrenciliğine son verilmesi kararı ile karşıllaşmıştır. Benzer şekilde başka bir öğrenci de sol eğilimli bir kitap okuduğu gerekçesiyle idarenin öğrenciliğini sonlandırması sonucu ile karşı karşıya kalmıştır. Bu kişilerin öğrenciliklerine son verilerek polis memuru olarak tayinleri çıkartılmıştır (Milliyet Gazetesi, 19 Haziran 1975).

\section{- Halk-Polis İlişkisi}

Polisin meşruiyetini kaybettiği ya da polis müdahalesinin meşru olarak algılanmadığ toplumda, şiddetin devlet-dışı aktörler tarafından özel kullanımı hem artar hem de hoş görülür (Jackson vd., 2013). Bu bağlamda MC dönemi polis-halk ilişkilerinin durumu analiz edilmeyi ayrıca hak etmektedir. Bu dönemde, polis uygulamaları ve Emniyet Teşkilatı’nın mevcut durumu sadece meslek mensuplarının tepkisiyle karşılaşmadı; toplumun genelinde de yankısını buldu. Dönemin polis uygulamaları, toplumun başta işçi ve öğrenci olmak üzere çeşitli kesimlerinde büyük tepkilere yol açttğı ölçüde kuruma ve üyelerine yönelik güven duygusu azaldı. Bu ise devlet-dışı şiddetin artışına ve siyasal şiddetin güçlenmesine neden oldu.

Pol-Der Genel Başkanı Kazım Ulusoy’un halk-polis arasında yitirilen güven duygusuna dikkat çekmek için söyledikleri bu açıdan önemlidir:

"Karşılaştığımız her şahıs, toplumsal olaylardaki polisin hatalarını ve hatta polisin bilerek öğrenciler üzerine ateş açtı̆̆ın, hedef gözeterek gençleri bile bile öldürdüğünü, bizleri küçümseyerek, lanetleyerek söylüyor. Gazeteler yazıyor, yazarlar dile getiriyor, olay içinde yaşayan ve de görevli olan polis arkadaşlarımız ağlayarak anlatıyor." (Pol-Der, Ocak 1976).

Halk ve polis arasında kopan bağın önemli nedenlerinden biri yukarıda bahsedilen kadrolaşma faaliyetleri sonrası polisin iktidarın polisi olarak nitelendirilmeye başlaması ise; bir diğer önemli 
nedeni de hükümet ortağı olan MHP’nin milis gücü olarak görev yapan Ülkücü Hareketin kendisini devletin yardımcı kuvvetleri olarak polisin yanında ve onunla işbirliği içerisinde sunmasidır.

Bu bağlamda, Pol-Der' in kuruluşunun temel gayesi olarak ortaya çıkan "halkın polisi" olma niyeti MC Hükümeti’nin son dönemlerine doğru daha da büyük anlam kazanmıştır. 1976-77 yılları polisin siyasal hedeflerle kullanıldığı yıllar olmuştur. Öner (2003), polise yöneltilen suçlamaların MC’nin iktidarda olduğu son iki yıllık dönemde arttığından bahsetmektedir. Bu durum, halkın gözünde polislerin devletin değil de hükümetin polisi haline geldiğini ve bu bağlamda da halkta kamu düzeni ile birebir ilişkili olan bir kurumun üyelerinin güvenirliklerini yitirmelerini göstermesi açısından önemlidir.

Diğer taraftan, aynı dönemde, polisin, bazı şiddet olaylarına göz yumduğu yönündeki iddialar özellikle 1976 yılı ile birlikte hız kazanmıştır. Bu dönem boyunca polis, Üniversitelere yönelik komando baskınlarında engelleyici ya da müdahale edici tavır takınmadığı gerekçesiyle eleştirilmiştir. Bu vesileyle ortaya çıkan şikâyetleri özellikle öğrencilerin Pol-Der’in şubelerine uğrayarak dile getirdikleri ya da bizzat bu şubelere uğrayarak Dernekten yardım istedikleri aktarılmaktadır (Öner, 2003).

Kamuoyunda ve özellikle muhalif basında 1976 yllı ile birlikte artan üniversitelere komando baskınları Emniyet Teşkilatı’nın ve polisin güvenilirliğinin sorgulanması ile neticelenmiştir. Mayıs 1976’da İTÜ’nün komandolar tarafından basılması üzerine Selçuk'un Cumhuriyet Gazetesi’nde kaleme aldığı yazı bu anlamda önemlidir:

"Bir üniversite düşünün ki öğretmen kürsüde, öğrenciler sırada, polis kapıda, kapı açıllyor, silahlı bir çete giriyor içeri, dan dan dan... Polis komandoların gelişine de gidişine de seyirci kaldı. Cinayetten sonra okulun kapıları kapatılsaydı, katiller yakalanabilirdi. Polis bunu da yapmadi" (Cumhuriyet Gazetesi, 1 Haziran 1976).

1977 yılında Milli Eğitim Bakanlığı’nı protesto eylemlerinde Gaziantep’te birisinin öldürülmesi sonrası artan gerginlik çok sayıda gözaltı ile sonuçlanmıştır. Bu olaylar sürerken, Cumhuriyet Gazetesi’nde (9 Ocak 1977) Olayların Ardındaki Gerçek köşesinde yapılan tespit kamuoyunun en azından bir kesiminde polisin algılanış biçimini göstermesi açısından önem taşımaktadır:

“...Böyle bir kentte bir avuç komandonun sürekli olaylar çıkarabilmesi bazı devlet güçlerinin desteğiyle olabilir. Çünkü halkın tutmadiğı eşkıyalık devletin içinden himaye görmeden ayakta duramaz."

Özellikle 1976 yılının ikinci yarısıyla birlikte DGM tartışmaları ekseninde işçi grevlerine aktif polis müdahalesi hem sağ hem de sol eğilimli gazetelerde ön plana çıkan haberler arasına girmiştir. Öyle ki Mumcu, baskı ve terörün son aylarda işçi kesimine doğru kaydırıldığını tespit etmekte ve çeşitli grevlerde işlenen iş̧̧i cinayetlerinden örnekler vermektedir (Cumhuriyet Gazetesi, 5 Temmuz 1976). Benzer şekilde Türk-İş Genel Başkanı Halil Tunç da son günlerde işçi haklarına karşı bir zihniyetin ortaya çıktığını vurgulamaktadır. Sıkıyönetimin ortadan kalkmasıyla birlikte artan 
işçi hareketliliği, DİSK'in üye sayısındaki artış ve son olarak DGM'lerin yeniden canlandırılması yasa taslağının hazırlanması sırasında DİSK'in net karşı duruşu sonrası hem işçi hareketi hem de buna karşı yürütülen polis müdahalesi iyice şiddetlenmiştir. Aliağa Rafinerisi gibi medyada öne çıkan geniş çaplı ve çok katılımlı grevlerdeki polis müdahalesi ve komandolarla işbirliği teşkilatı yine tartışmaların ve artan siyasal şiddetin merkezine koymuştur. 1976 yllının Temmuz ayında direnişteki Genel Sigorta işçileri, polisin kendilerine karşı tam bir savaş harekâtına giriştiklerini belirtmektedirler (Cumhuriyet Gazetesi, 18 Temmuz 1976). Bank-İşs sendikasına girdikleri için işten çıkarılan arkadaşlarının geri alınmaları için direnişe geçen işçiler, valiye gönderdikleri açık mektupta 5 Temmuz sabahı polislerin girişimlerini sükûnetle çözümlediklerini, ancak 8 Temmuz ve 14 Temmuz'da polisin tam bir savaş harekâtına girişerek kahvelerde oturan genç kızları bile copladıklarını iddia etmişlerdir. İşçilerin önemle sorguladıkları soru "35 gün hiçbir olay çıkmamasına rağmen polisin neden müdahale ettiğine" dairdir. Diğer taraftan işçi örgütlenmeleri ve hareketlerini destekleyen kişilere de polis tarafından müdahalede bulunulmuştur. Polisçe vurulup öldürülen işçi Ökkeş Karayiğit'in cenazesini almak üzere morga gelen Avukat Bozkurt Nuhoğlu ve cenazeyi almaya gelen diğer kişilerin Alemdar Karakolu’na polisçe götürüldükleri ve burada altı saat boyunca işkence altında tutuldukları basının gündemine oturmuştur. Avukat Nuhoğlu’na polise karşı davaların müdafiliğini almaması yönünde telkinde bulunulduğu da yine tanıkların ifadesinden anlaşılmaktadır (Cumhuriyet Gazetesi, 3 Temmuz 1976).

Halk ve polis arasında kopan bağın tamirini siyasal şiddetin önlenmesinin temeline yerleştiren Pol-Der bu amaçla önemli girişimlerde bulunmuştur. Yayın organı Pol-Der Gazetesi aracıllğıyla halkla ilişkilerimiz adlı bir köşe oluşturulmuş, okuyucu mektuplarında ana tema olarak halkpolis ilişkisinin bozulmuş olması kamuoyunun dikkatine sunulmuş ve polisin bu konudaki duyarlığı arttırılmak istenmiştir. Polis Arkadaş köşesi yayına hazırlanmış ve çok sayıda karikatür aracılığıyla polisin, halkın kendisini suçladığının ve bu konuda da haklı olduğunun farkında olduğu gösterilmek istenmiştir. Ancak Pol-Dere yönelik baskılar ve üye polislerin uğradığ1 muameleler halk-polis bağının yeniden inşasını büyük ölçüde imkânsız kılmıştır. ${ }^{12}$

\section{- Polis ve Yargı}

Devletin baskı aygıtlarının önemli bir bileşeni olan Polis Teşkilatı’nı kendi başına bir kuvvet olarak nitelendirmek doğru olmaz. Polis, bir baskı aygıtı olarak farklı türden toplumsal kontrol mekanizmalarıyla da ilişki ve etkileşim halinde bulunur. Bunun en önemli örneklerinden biri de polisin devletin yargı gücüyle ilişkisinde gözlemlenir. Polis, suçun savcıllğa intikal ettirilmesinde, kovuşturulmasında ve delillerin toplanmasında yargı mekanizması ile deyim yerindeyse tam bir işbirliği içinde bulunur (Uysal, 2011:74-75). Polis ile yargı faaliyetlerini MC Hükümeti döneminde yakalanan ve tutuklanan ülkücülerin korunup kollanmasına yönelik emirler, hakkında yakalama emri çıkarılan üst düzey Ülkücülerin polis tarafından kovuşturulmaması, buna karşın, öğrencilerin dövülmesi, hatta bazı merkezlerde işkenceye varan uygulamalar polis içerisinde de

12 Pol-Der kapatıldığında 18 bin kişiye yakın üyesi bulunmaktaydı. Darbe sonrasında ise polis içerisindeki 12 bin civarı sosyal demokrat veya sol eğilimli Pol-Der üyesi polisler ya 1402'lik olmak suretiyle ya trafik polisi olmak suretiyle ya da doğrudan erken emekli edilmek suretiyle cezalandırılmıştır. Böylece mesleki eğitime sahip yüksek tahsilli kimseler polis kadrolarından ayıklanmış ve polis büyük ölçüde sağcı bir yapılanma halini almıştır (Uysal, 2006). 
taraf tutma eğilimini arttırmıştır. Ayrıca şiddet olaylarına karışan yakaladıkları bazı militanların amirlerinin, bu kişileri "neden” yakaladıklarına dair soruları ertesinde serbest bırakıldıklarına tanıklık etmeleri polislerin hem meslekle hem de halkla aralarındaki ilişkiyi derinden zedelemiştir (Öner, 2003:73-83). Nurhan Varlı, Hacettepe'nin yakınındaki Mali Bilimler Yüksekokulu’ndaki görevi sırasında giriştiği öğrencilerin aranması çalışmalarında engellendiğini, sağcıların hâkim olduğu bu kısımda polisin arama yapmadığının meslektaşları tarafından kendisine hatırlatıldığını ve ssrarla bu öğrencileri araması sonrasında bu görevin kendisinin fakültelerdeki son görevi olduğunu anılarında aktarması Öner’in anlattıklarına paralel görünmektedir (Yiyenoğlu, 1995).

Nihayetinde MC Dönemi boyunca Emniyet Teşkilatının geçirdiği yapısal dönüşüm dönemin siyasal şiddetini büyük ölçüde yoğunlaştırmıştır. Hükümetin teşkilat bünyesinde yürüttüğü kadrolaşma çalışmaları polisin toplumla ilişkisinde ciddi yıkıntılar meydana getirmiş ve bu sonuca dair kurum bünyesinde ciddi bir tepki gelişmiş ve mücadele yaşanmıştır. Kamu düzenini sağlamakla görevli ve aynı zamanda devletin topluma en yakın kurumu olarak polis teşkilatında dönem dâhilinde yaşanan gelişmeler genel olarak devlet-toplum ilişkisinde yaşanan gerilimin bizzat gözlemlenebildiği bir mikro alan olarak belirmesi bakımından siyasal şiddet analizinde kilit bir konuma yerleşmektedir.

\section{Sonuç}

Elinizdeki çalışma, siyasal şiddeti "neden” sorusu üzerinden anlamak ve makro nedensellikler temelinde açıklamak yerine siyasal şiddetin zamansal ve mekânsal bağlamda nasıl işlediğine bakmaya çalışmıştır. Belirli tarihsel koşullar altında devletin baskı mekanizma ve pratiklerinin siyasal aktörler tarafından nasıl işletildiği bu çalışmanın konusunu oluşturmuştur. 30 Mart 1975 y1lında kurulan ve dört sağ partinin (AP, MHP, MSP ve CGP) birleşiminden oluşan I. Milliyetçi Cephe hükümetinin siyasi kadro ve partilerinin siyasal şiddeti nasıl yönettikleri sorusu bu çerçevede önem kazanmıştır.

Diğer taraftan çalışma Türkiye'de döneme ve siyasal şiddet konusuna dair literatürde ihmal edilen devlet alanına odaklanmayı hedeflemiştir. Bunun için, çalışma, devleti siyasal şiddet analizinin etkin ve daimi bir öznesi olarak ele almayı amaçlamıştır. Şiddeti otonom bir süreç olarak gören, devlete ise sahip olamayacağı bir hakem rolü atfederek onu topluma dışsal olarak tanımlayan yaklaşımların döneme dair analizlerinin tersine, araştırma, devleti siyasal şiddet analizi kapsamında hak ettiği merkezi konuma taşımak istemiştir. Bu nedenle araştırma, devlet aygıtını -baskı aygıtları temelinde- şiddet analizinin önemli bir bileşeni olarak araştırmanın merkezine almıştır.

MC Hükümeti iç güvenlik ve devletin bekası amacıyla ortaya koyduğu baskı pratik ve mekanizmalarını güçlü devlet söylemi temelinde meşrulaştırmaya ve bu bağlamda kamu düzeni ittifakını genişletmeye çabalamıştır. Sıkıyönetim pratiği, MC Hükümeti’nin iktidarının başladığı dönemde artan toplumsal muhalefet karşısında emniyet mekanizması işlevi görmüştür. 
İç tehdit olarak nitelendirilen muhalif hareketler karşısında işletilmesi bir baskı pratiği olarak sıkıyönetimin anlam ve işleyişini yeniden tasarlamıştır. Son olarak hükümetin elinde önemli bir silah olarak kullanılmaya çalışıldığı ölçüde polisin içinde direniş alanları nüvelenmiş; halkla kopan bağa rağmen halkın rızasını alma ihtiyacı örgütlenmenin iç yapısında derin gerilimler yaratmıştır.

Elbette ki, siyasal şiddet mevzusu çok aktörlü ve ilişkisel bir sürece işaret eder (Tilly, 2003). Kapsamlı bir siyasal şiddet analizi ancak aşırı sağ, aşırı-sol ve devlet zorunu/şiddetini bir arada ilişkisel anlamda incelemekle mümkün kılınabilir. Bu çalışma, bu bağlamda, ancak bir bütünün belirli bir parçasını analiz ederek literatüre ufak bir katkı sağlamayı hedeflemiştir. Polisin bölündüğü ve kadrolaştığı, sıkıyönetimlerin sürekli olarak uzatılarak grev, toplu sözleşme ve öğrenci hareketleri üzerinde sürekli bir denetimin kurulmak istendiği, hepsinin güçlü devlet arayışı ve devlet aklı ihtiyacı temelinde meşrulaştırılmak istendiği bu dönem şüphesizdir ki siyasal şiddetin tarihselleştirilmesi konusunda büyük ve kapsamlı bir analiz alanı sunmaktadır. 


\section{Kaynakça}

Aydınoğlu, E. (2007) Türkiye Solu: 1960-80, İstanbul: Versus.

Ataay, F. (2005) “Kriz Kıskacında CHP Hükümeti 1978-1979”, Yayınlanmış Doktora Tezi, Ankara Üniversitesi Sosyal Bilimler Enstitüsü Siyaset Bilimi ve Kamu Yönetimi Doktora Programı, Ankara.

Aymes, M., B. Gourisse ve E. Massicard (2014) L'art de l'État en Turquie: Arrangements de l'action publique. De la fin de l'Empire ottoman à nos jours, Paris: Karthala.

Bora, T. (1992) “Terör, Devlet ve Türk Sağı”, Birikim Dergisi, Mayıs: 48-57.

Bora, T. (2011) "Polis ve Cemaat”, Birikim Dergisi, Nisan-Mayıs: 264-265.

Davenport, C. (2007) "State Repression and Political Order", Annual Review of Political Science, 10: 1-23.

Bozarslan, H. (2009) “Bir Bölücü ve Birleştirici Olarak Şiddet”, Toplum ve Bilim, 116: 6-20.

Bozarslan, H. (2014) “Sunuş”, içinde G. Çeğin ve İ. Şirin (der.) Türkiye’de Siyasal Şiddetin Boyutları, İstanbul: İletişim, 9-30.

Della Porta, D. (2006) Social Movements, Political Violence and the State: A Comparative Analysis of Italy and Germany, Cambridge: Cambridge University Press.

Della Porta, D. (2008) "Research on Social Movements and Political Violence", Qualitative Sociology, 31(3): 221-230.

Della Porta, D., O. Fillieule (2004) "Policing Social Protest", in D. A. Snow, S. A. Soule and H. Kriesi (eds.) The Blackwell Companion to Social Movement, Oxford: Wiley-Blackwell, 217-241.

Della Porta, D., S. Tarrow (1987) "Unwanted Children: Political Violence and the Cycle of Protest in Italy, 1966-1973”, European Journal of Political Research, 14: 607-632.

Dorronsoro, G. (2006) La Turquie conteste: Mobilisations sociales et régimes sécuritaires, Paris: CNRS Éditions.

Ergin, M. (1975) Türkiye’nin Bugünkü Meseleleri, İstanbul: Güryay Matbaacilık.

Ergut, F. (2001) "Polis Çalışmaları İçin Kavramsal Bir Çerçeve", Amme İdaresi Dergisi, 34(1): 59-78.

Ergut, F. (2012) Modern Devlet ve Polis. Osmanlidan Cumhuriyet’e Toplumsal Denetimin Diyalektiği, (2. Baskı), İstanbul: İletişim.

Ergut, F. (2014) “Devlet ve Politik Şiddet: Latin Amerika ve Türkiye’de Gerilla Hareketleri”, içinde G. Çeğin ve İ. Şirin (der.) Türkiye’de Siyasal Şiddetin Boyutları, İstanbul: İletişim, 207-224.

Goldstein, R.J. (1978) Political Repression in Modern America: From 1870 to the Present, Cambridge, MA: Schenkman.

Goldstone, J. A (ed.) (2003) State, Parties and Social Movements, Cambridge: Cambridge University Press.

Goodwin, J. (2007) “Devrimci Terörizmi Anlamak” (çev. F. Ergut), içinde F. Ergut ve A. Uysal (der.), Tarihsel Sosyoloji: Stratejiler, Sorunsallar, Paradigmalar, Ankara: Dipnot Yayınları.

Gourisse, B. (2008) "Pluralité des rapports aux normes professionelles et politisation des pratiques dans la police turque des années 1970", European Journal of Turkish Studies, 8.

Gourisse, B. (2011) "Variation des ressources collectives et organisation des activités de violence au sein du mouvement nationaliste en Turquie (1975-1980)”, Cultures \& Conflits, 81-100.

Gourisse, B. (2012) “Participation électorale, pénétration de l’État et violence armée dans la crise politique turque de la seconde moitié des années 1970”, Politix, 98: 171-193.

Gönen, Z., Z. Başer, M. Uçum ve B. Berksoy (2013) “Polis Yasalarının Ruhu: Mevzuatta Söylemler, Araçlar ve Zihniyetler”, TESEV Demokratikleşme Programı Siyasa Raporları Serisi, İstanbul: TESEV Yayınları.

Gürel, B. (2004) "Communist Police! The State In The 1970s Turkey", Journal of Historical Studies, 2: 1-18.

Jacoby, T. (2010) "Political Violence, the War on Terror and the Turkish Military", Critical Studies On Terrorism, 3(1): 99-118. 
Mert, N. (2007) Merkez Sağın Kısa Tarihi, İstanbul: Selis Kitaplar.

Orlow, D. (1982) "Political Violence in Pre-Coup Turkey", Terrorism, 6(1): 53-71.

Necleous, M. (2006) "The Problem with Normality: Taking Exception to Permanent Emergency”, Alternatives, 31: 191-213.

Öner, S. (2003) Halkın Polisi Pol-Der Anıları, İstanbul: İletişim.

TBMM Tutanak Dergisi (1975) B: 9, 30 Nisan 1975.

Sancar, M. (1997) “Devlet Aklı, Hukuk Devleti ve Devlet Çatısı”, Birikim, 93/94: 80-90.

Sayari, S. (2010) "Political Violence and Terrorism in Turkey, 1976-1980: A Retrospective Analysis", Terrorism and Political Violence, 22(2): 198-215.

Sommier, I. (2012) Devrimci Şiddet, (çev. I. Ergüden), İstanbul: İletişim.

Tilly, C. (2003) The Politics of Collective Violence, New York: Cambridge University Press.

Tilly, C. (2009) Kolektif Şiddet Siyaseti, (çev: S. Özel), Ankara: Phoenix.

Turan, Ö. (2013) “Alternatif Tahayyüller, Devingenlik, Popülizm: 1970’ler İçin Bir Çerçeve Denemesi”, Toplum ve Bilim, 127: 3-24.

Uysal, A. (2006) “Cop Gölgesinde Politika: Türkiye'de Toplumsal Olay Polisliği ve Sokak Eylemleri”, Mülkiye Dergisi, XXX(253): 79-94.

Uysal, A. (2001) "Devletin Güvenliği ve Toplumsal Muhalefet Eylemleri: “Kalemli Çete Örneği”, Birikim Dergisi, 146: 64-84.

Uysal, A. (2012) "Sokak Eylemlerinde ve Polis Denetiminde Tarihsel Süreklilik ve Kopuş", içinde F. Ergut ve A. Uysal (der.) Tarihsel Sosyoloji Stratejiler, Sorunsallar, Paradigmalar, Ankara: Dipnot Yayınları, 375-408.

Ünsal, A. ve R. Keleş (1982) Kent ve Siyasal Şiddet (1975-1979), Ankara: Ankara Üniversitesi Siyasal Bilgiler Fakültesi Yayınları.

Üskül, M. Z. (2014) Bildirileriyle 12 Mart 1971 Dönemi Sıkıyönetimi, İstanbul: Tarih Vakfı Yurt Yayınları.

Yiyenoğlu, Ç. (1995) Sakıncalı Kadın Polis Nurhan Varlinın Anıları, İstanbul: Çağdaş Yayınları.

\section{Gazeteler ve Dergiler}

Cumhuriyet, 14 Ocak 1976, 17 Ocak 1976, 4 Mayıs 1976, 11 Haziran 1976, 5 Temmuz 1976,

15 Temmuz 1976, 18 Temmuz 1976, 9 Ocak 1977

Tercüman, 22 Ekim 1975, 16 Şubat 1976

Pol-Der, Kasım 1975, Aralık 1975, Ocak 1976, Mayıs 1976

Devlet, 29 Eylül 1975

Yankı Dergisi, 16-22 Haziran 1975, 10-16 Ağustos 1975, 24-30 Ağustos 1975 